\title{
Muhasebe Meslek Mensuplarının İş Stresi, İş Performansı ve İş Tatmini Düzeyleri Üzerinde Kontrol Odağı Etkili Bir Faktör Mü?*
}

\author{
Bilgehan TEKIN ${ }^{* *}$ \\ Burak DENIZ***
}

\section{$\ddot{O Z Z E T}$}

Bu araştırmanın amacı; kişiliğin bir boyutu olarak kabul edilen kontrol odă̆ının muhasebe meslek mensuplarının iş stresi, iş performansı ve iş tatminini nasıl etkilediğini ortaya koymaktır. Bu amaçla Türkiye'nin farklı bölgelerinde faaliyet gösteren ve anket uygulamasına gönüllü olarak katılan 178 muhasebe meslek mensubu katılımcıya 4 farklı ölçek içeren anket uygulaması yapılmıştır. Toplanan veriler üzerinden katılımcıların kontrol odağı davranışları ile iş stresi, iş performansı ve iş tatmini düzeyleri arasındaki ilişki incelenmiştir. Yapılan araştırma sonucunda, katılımcıların büyük bir çoğunluğunun iç kontrol odaklı bir kişilik yapısına sahip oldukları görülmüştür. Kontrol odağıyla, iş tatmini ve iş stresi arasında anlamlı bir ilişki tespit edilmiş olunup, iş performansı ile anlamlı olmayan bir ilişki tespit edilmiştir. Dış kontrol odaklı katılımcıların iş stresi düzeyi, iç kontrol odaklı meslek mensuplarından daha yüksek bulunmuştur. Ayrıca, dış kontrol odaklı katılımcıların daha az iş tatmin düzeyine sahip oldukları belirlenmiştir.

Anahtar Kelimeler: Kontrol Odağı, İş Stresi, İş performansı, İş Tatmini, Muhasebe Meslek Mensubu.

JEL Sinıflandirması: M40, M41, J28.

\section{Is Locus of Control an Effective Factor on Job Stress, Job Performance and Job} Satisfaction Levels of Accounting Professionals?

\section{ABSTRACT}

The aim of this research is to reveal how the locus of control which is accepted as a dimension of personality affects job stress, job performance and job satisfaction of accounting professionals. For this purpose, the survey which had included 4 different scales was applied to 178 accounting professionals operating in different regions of Turkey as voluntary participant. The relationship between the locus of control behaviors of the participants and the job stress, job performance and job satisfaction levels were examined. As a result of the research, it was seen that the majority of the participants had internal locus of control. A significant relationship was found between job satisfaction and job stress with locus of control and no significant relationship was found with job performance. The level of job stress of external control-oriented participants was higher than those of internal control-oriented professionals. In addition, external control-oriented participants were found to have fewer job satisfaction levels.

Keywords: Locus of Control, Job Stress, Job Satisfaction, Job Performance, Professional Accountant.

Jel Classification: M40, M41, J28.

Makale Gönderim Tarihi: 20.01. 2019

Makale Kabul Tarihi: 19.02.2019

Makale Türü: Araştırma Makalesi

\footnotetext{
* Bu çalışma Çankırı Karatekin Üniversitesi (ÇAKÜ) Sosyal Bilimler Enstitüsü tarafından kabul edilen "Muhasebe Meslek Mensuplarının İş Stresi, İş Performansı ve İş Tatmini Üzerinde Kontrol Odağının Etkisi" başlıklı yüksek lisans tezinden çıkarılmıştır.

** Dr. Öğr. Üyesi, Çankırı Karatekin Üniversitesi, İİBF, İşletme Bölümü, btekin@karatekin.edu.tr. ORCID ID: 0000-0002-4926-3317.

*** Çankırı Karatekin Üniversitesi, Sosyal Bilimler Enstitüsü, burakdeniz1993@ gmail.com.
} 


\section{GİRIŞ}

Muhasebe mesleği, ulusların finansal yapısını meydana getiren özel ve devlete bağlı örgütlerin muhasebe ve denetimi ile tüm finansal çalışmaların kanunlara, kaidelere, prensiplere, standartlara ve metotlara dayanan, objektif, ketum ve güvene dayalı bir davranışla gerçekleştirilmesi gereken bir meslektir (İbiş, 2002). Muhasebe meslek mensupları; işlerinin gereği olarak devlete, mükelleflere, çalıştıkları kurumlara ve topluma karşı sorumlulukları olan kişilerdir. Muhasebe meslek mensupları, sorumluluklarını yerine getirmeye çalışırken bazı engeller ve sorunlarla da karşılaşabilmektedirler. Günlerinin çok büyük bir kısmını işyerlerinde geçirmek durumunda olan muhasebe meslek mensuplarının yaptıkları işlerin en iyi düzeyde sonuç verebilmesi için iş performansı düzeylerinin en üst seviyede olması gerekmektedir. Meslek mensuplarının iş performansı düzeylerinin istenilen seviyede olabilmesinin yolu ise yaptıkları işten duydukları memnuniyet ve tatmin seviyelerinin mümkün olduğunca yüksek olmasından geçmektedir. $\mathrm{Bu}$ nedenle meslek mensuplarının yaşadıkları iş stresinin en aza indirilmesi gerekir.

İş stresi ve iş tatminsizliği, örgütler açısından geri dönüşü olmayan ve maliyeti yüksek olumsuz sonuçlara neden olabilmektedir. Aşırı ve uzun süreli strese maruz kalma ve işten duyulan tatminsizliğin en önemli etkisinin iş performansında meydana gelen azalma olduğu rahatlıkla ifade edilebilir. Bu durumların oluşmasında ayrıca meslek mensuplarının kişilik yapısı da oldukça önemli bir rol oynamaktadır (Tanç, 2016:44).

İnsanlar farklı kişilik özelliklerine sahiptirler. Kimi doğuştan gelen, kimi sonradan kazanılan bu farklılıklar yetiştirilme tarzının, eğitim süreçlerinin ve hayat tecrübelerinin etkisi altında şekillenir. İnsanlar, farklı olarak geldikleri dünyada yaşadıkları farklı olaylar sebebiyle farklı kişilik özelliklerine sahip olurlar. Bu noktada kontrol odağı, farklı bireylerin ortak kişilik özelliklerini niteleyen önemli kavramlardan biri olup, bireylerin yaşadıkları olayların sorumluluğunu nereye bağladıklarıyla ilgilidir. Yaşadıkları olayların sorumluluğunu kendi davranışlarının sonuçlarına bağlayan bireylere iç kontrol odaklı, kendi dışındaki başka güçlere (güçlü olan diğerleri, şans ve kader) bağlayan bireylere de dış kontrol odaklı bireyler denilmektedir (Akkaya, 2015: 1).

Kontrol odağı konusunu kişilik özelliği olarak değerlendirip ele alan çalışmaların sonuçlarına göre, iç kontrol odağı yapısına sahip bireylerin, dış kontrol odağı yapısına sahip bireylere göre daha olumlu kişilik özelliklerine sahip olduğu görülmüştür. Diş kontrol odağı, daha çok düşük benlik saygısı, depresyon, baş ağrıları, sinir hastalıkları ve diğer psikofizyolojik semptomlar ve psikopatoloji ile ilişkilidir (Küçükkaragöz, 1998:42). Bireylerin yaşadıkları olayları davranışlarıyla ilişkilendiren bireylerin, kendi yaşamlarında doğru kabul edilmeyen olayları değiştirmede daha 1srarcı oldukları, talih ya da alın yazısı gibi kendinden bağımsız güçlere bağlayan bireylerin ise daha az girişimci ve daha az mücadeleci oldukları belirtilir (Küçükkaragöz, 1998:42).

İç ve dış kontrol odağı davranış özellikleri, tüm meslek gruplarında olduğu gibi muhasebe mesleğiyle meşgul olan bireyler için de söz konusudur. Tanç (2016) ve Chen ve Silverstone (2008), yaptıkları çalışmalarda iç kontrol odağına sahip meslek mensuplarının, dış kontrol odağına sahip meslek mensuplarına göre daha olumlu bir kişilik yapısına sahip olduklarını, yaptıkları işten daha fazla mutluluk duyduklarını, daha az iş stresi yaşadıklarını ve daha yüksek bir iş performansına sahip olduklarını belirtmektedirler. 
Türkiye'de muhasebe meslek mensuplarının iş ile ilgili sahip oldukları psikolojik (iş stresi, iş performansı ve iş tatmini vb.) ve davranışsal faktörler üzerine gerçekleştirilmiş çalışmaların sayısı oldukça sınırlıdır. Bu tespitler göz önüne alınarak yapılan bu araştırmanın amac1; kişiliğin bir boyutu olarak kabul gören kontrol odağının muhasebe meslek mensuplarının iş stresi, iş performansı ve iş tatminini hangi boyutta etkilediğini ortaya koymaktır. Bu çalışmada Türkiye'de faaliyet gösteren, Serbest Muhasebeci (SM), Serbest Muhasebeci Mali Müşavir (SMMM) ve Yeminli Mali Müşavir (YMM) unvanına sahip meslek mensuplarının kontrol odağı davranışları ve iş ile ilgili yaşadıkları stres, performans ve tatmin düzeyleri arasındaki ilişki ele alınmaktadır.

Çalışmanın bundan sonraki başlıkları altında öncelikle kontrol odağı, iş stresi, iş tatmini ve iş performansı kavramlarına değinilecek daha sonra konu ile ilgili literatüre ve hipotezlere yer verilecektir. Sonraki bölümde araştırma kapsamında yapılan analizler ve sonuçları sunulacak olup, son olarak çalışmanın sonuç ve değerlendirme bölümü yer alacaktır.

\section{KAVRAMSAL ÇERÇEVE}

\subsection{Kontrol Odağı Kavramı}

Kontrol odağı, Rotter tarafindan ortaya atılmış toplumsal öğreti kavramı ölçeğinde meydana getirilmiş ve bir kimlik özelliği olarak tanımlanarak kullanılmıştır. Kontrol odağı; genel olarak bireylerin yaşamlarında elde ettiği sonuçlara bağlı ifadelerin ve kazanımların başarı veya başarısızlıkların nelerle ilişkilendirildiğiyle ilgilidir (Çaylı, 2013:3). Bu ilişkilendirilen konular daha çok kişilerin kendilerinden başka şans, güçlü tanıdıklar, kader vb. etkenlere dayandırabileceği gibi, kendilerinin yaptıkları davranışların bir sonucu olarak da kabul edilebilir (Solmuş, 2004: 196). Rotter, kontrol odağı kavramını aşağıdaki şekillerde ifade etmiştir ( Rotter, 1966: 1, Sergici, 2013: 45):

- $\quad$ Bir kişinin elde ettiği mükafat ve cezaların kişinin kendisi tarafından mı veya kişinin kendinden başka unsurlar tarafından mı denetlendiğine yönelik genel bir beklentidir, şeklinde ifade edilmektedir.

- $\quad$ Bireyin kendini ifade ederken ya da tanımlarken kendi yaşamındaki olaylar karşısında kendini yerleştirdiği yer, benlik kontrolünün odağını oluşturmaktadır.

- Kişilerin yaşamları boyunca karşılaştıkları iyi ya da kötü olayların nedenlerini, kendilerine ya da kendi iradesi dışındaki kişilere, şans kader gibi unsurlara bağlamasıdır.

- $\quad$ Bireyin kendi davranışları merkezinde kontrol gücüne sahip olduğuna veya başka bireylerin altında olduğuna dair genel bir beklentiye sahip olmasıdır.

- Bireyin kendilerini etkilemesi açısından sonuçları pozitif ya da negatif olan olayları kendi yetenek, beceri ve davranışlarının sonuçları ya da kendisi dışındaki etkenlerin (şans, kader, talih vb.) gerçekleştirdiği sonuçlar olarak algılamasıdır.

Bireylerin hayatları boyunca karşılaşacağı olumlu olayları ödül; olumsuz olayları ceza olarak düşünürsek, kişilerin davranışları bakımından ortaya iki eğilim çıkacaktır. Bunlardan biri; mükafat ve cezanın bireyin iradesi dışındaki diğer güçler tarafından yönlendiği, kontrol edildiği ve kişisel çabaların ödüle ulaşma veya cezadan kaçma konusunda bir işe yaramayacağı eğilimidir. Diğeri ise kişilerin bireysel çabalarının ödüle ulaşma ya da cezadan 
kaçma konusunda etken olduğu eğilimidir. Bu eğilimlerin hepsine "Kontrol Odağı" denir (Yeşilyaprak, 2015: 244).

\subsection{1. İç Kontrol Odaklıık}

Rotter, kontrol odağını iki gruba ayırmaktadır. Birinci grup, çevrelerini kendi yararlarına değiştirilebileceklerine inanan iç kontrol odaklılara girerken, ikinci gruba ise daha çok çevrenini denetiminde olduklarına inanan dış kontrol odaklılara girmektedir (Atılmış, 2016: 18).

\begin{tabular}{c|c}
\hline İç Kontrol Odă̆ı & Dış Kontrol Odă̆ı \\
\hline $\begin{array}{c}\text { Kişi, davranışlarının kendi kişisel kararları ve çabaları } \\
\text { tarafından yönlendirildiğine inanır. }\end{array}$ & $\begin{array}{c}\text { Kişi; davranışlarının kader, şans veya diğer dış koşullar } \\
\text { tarafından yönlendirildiğine inanır. }\end{array}$ \\
\hline
\end{tabular}

Kaynak: (Akbolat vd., 2011: 25)

Şekil 1. İç ve Diş Kontrol Odağ

İlk grupta yer alanlar, iyi ya da kötü kendilerine olanların nedenini kendileri ya da kendi davranışları olduğuna inanma eğilimindedir (Dönmez, 1984: 146). Bu eğilimde olanlar, iç kontrol odaklı bireyler olarak adlandırılır. Buradan hareketle iç kontrol odağı, kuramsal olarak bireyin kendi yaşamından olan olayların " kendi kontrolü” altında olduğuna (Dağ, 1990: 204) ya da davranışları vasıtasıyla yaşam ve çevresini bir miktar kontrol etmesinin mümkün olduğuna işaret eder (Hexel, 2003: 1261). İç kontrol odaklı bireylerin özellikleri şöyle sıralanabilir: (Çakar, 1977: 35).

- $\quad$ Kendilerine güvenen ve bağımsız düşünüp bağımsız çalışabilen kişilerdir

- Soyut düşünebilme gücü gelişmiş olup karmaşık olayları hızlı bir şekilde değerlendirip çözmektedirler (K1ral, 2012: 60).

- Davranışlarının sorumluluklarını üstlenirler (Dönmez, 1986: 37).

- $\quad$ Daha objektiftirler (Yeşilyaprak, 2015: 245).

- $\quad$ Şansa çok inanmazlar (Dilmaç, 2008: 4).

245).

- $\quad$ Çevreleriyle etkili iletişim kurmada başarılı ve etkindirler (Yeşilyaprak, 2015:

- Güvenilir, uyumlu davranışlar gösteren ve sorumluluklarını bilen kişilerdir (Dönmez, 1983: 39).

- Baskılara boyun eğmeyen, kendi yargılarına güvenen bireylerdir (Dönmez,1983: 39; Solmuş, 2004: 196; Dilmaç, 2008: 4).

- $\quad$ Stresle baş etme yeterlilikleri yüksektir (Kral, 2012: 60). 
- $\quad$ Büyük ölçüde öz saygı ve olumlu öz kavramına sahiptirler ( Dağ, 1991: 11; Yeşilyaprak, 2015: 246).

- $\quad$ Okul başarıları ve yarışma sınavlarındaki başarıları yüksektir (Tümkaya, 2000: 1; Demirkıran, 2006:36-41; Çetin, 2008: 85: 62- 41; Basım ve Şeşen, 2008: 49-64; Dilmaç, 2008: 4).

- $\quad$ Entelektüel ve akademik etkinliklere fazla zaman ayırırlar (Çakar, 1997: Solmuş, 2004: 196; Şengüder, 2006: 17; Dilmaç, 2008: 4).

- Sağlıklarına özen gösterirler ve duygusal yönden sağlıklı ve dengeli kişilerdir (Çınar ve Karcıoğlu, 2012: 286; Yeşilyaprak, 2015: 245).

- Araştırmayı seven, kendini ve çevresini geliştirmek için eyleme giren, atılgan, girişimci, soru soran ve amaçlarını gerçekleştirmek için uğraş veren kişilerdir (Tümkaya, 2000: 1; Çinko 2009: 27).

- Yaşamları düzenlidir ve zamanı etkili kullanırlar (Yeşilyaprak, 2015: 245; Çakar, 1977: 48).

- $\quad$ Sosyal ortamlara girmekte ve sosyal faaliyetlerde bulunma konusunda istekli bireylerdir (Dönmez, 1986: 33).

- $\quad$ Toplumsal olaylarda aktiftirler (Dilmaç, 2009: 4).

- $\quad$ Engellemeler karşısında daha yapıcı tepkiler ortaya koyarlar (Bolat; 2016: 47).

\subsubsection{Dış Kontrol Odaklılık}

Rotter'a göre dış kontrol odağı; bir olayın veya sonucun, kişi tarafından kendi davranışlarından bağımsız olarak sonuçlandığı şeklinde algılanması durumunda, bunun tam olarak "şans, kader ve kısmet" in sonuçları olarak benimsenmesidir. Bu durumun dışında birey, yaşadıklarının sebebini kendisini kuşatan büyük ve karmaşık güçler olarak da değerlendirebilir. Birey, başına gelen olayların genellikle kendisi dışındaki etkenler tarafından belirlendiğine inanır (Basım ve Şeşen, 2008: 160).

Dış kontrol odağına sahip bireyler, kaderlerini değiştiremeyecekleri inancına sahiptirler. Bu bireyler, kendi çevresinde meydana gelen olayların veya durumların sonuçlarını, kendi yeteneklerinden ve kişilik özelliklerinden değil; kendilerinin kontrolü dışında gerçekleşen olaylardan kaynaklandığını düşünmektedirler (Rotter, 1990: 491; Dönmez, 1985: 37). Bu sebeplerden dolayı, bireylerin kazanımlara, ödüllere ve cezalara yaklaşımlarında kendi gayretlerinin önemli olamayacağı şeklindeki algı, diş kontrol odağını ifade etmektedir (Phares, 1976: 25; Sungur, 1992: 266). Genel olarak diş kontrol odaklı kişilerin özellikleri şu şekilde sıralanabilir:

- Kendilerini yalnız hissederler (Küçükkaragöz vd, 1988: 30)

- Deneyim sonucu öğrendikleri durumlar konusunda doğru bildiklerinden şaşmayan, yeniliklere kapalı bireylerdir (Ören, 1991: 21). 
- Sorumluluk almak istemezler (Tümkaya, 2000: 1).

- Kendini tanımada ve yeteneklerinin farkında olmada yetersizdirler (Tümkaya, 2000: $1)$.

- Kendi algılamalarında sorunlar yaşayan, kendilerini olumsuz gören kişilerdir (Yağışan vd, 2007: 5).

- İnsan ilişkilerinde yetersiz ve sosyal becerileri zayıf olan bireylerdir (Dönmez, 1983: 39; Solmuş, 2004: 196; Dilmaç, 2008: 4).

- Kendilerinin özgür olamadıklarını, dış güçlerin esiri ve kurbanı olduklarını düşünürler (Dönmez, 1983: 39; Solmuş, 2004: 196; Dilmaç, 2008: 4).

- Düşük beklenti düzeyine sahiptirler (Dönmez, 1983: 39; Solmuş, 2004: 196; Dilmaç, 2008: 4).

- Başarılı olduklarında bu başarıyı küçümsemektedirler (Dönmez, 1983: 39; Solmuş, 2004: 196; Dilmaç, 2008: 4).

- Saldırgan tutumlar sergilerler (Çinko, 2009: 27).

- Daha çok dogmatiktirler (Pektaş, 2013: 47).

- Kuşkucudurlar (Pektaş, 2013: 47).

- Kendilerine ve başka insanlara güvenmezler (Yeşilyaprak, 2015: 244).

- Savunma mekanizmalarına çok sık başvururlar (Yazıcı, 2014: 720).

- Kendini kabul ve kendine öz saygı düzeyleri düşüktür (Yeşilyaprak, 2015: 244).

- Depresif özellik taşırlar ve bu özellikleri sürekli artma eğilimindedirler (Yazıcı, 2014: 720).

Yapılan araştırmalar; iç kontrol odağına sahip bireylerin pozitif kişilik özelliklerinin olduğunu, dış kontrollü bireylerin ise iç kontrol odaklı bireylerin tam tersi özelliklere sahip olduğunu göstermektedir. Gangai ve diğerleri (2016) tarafindan yapılan çalışma incelendiğinde; iç ve dış kontrol odaklı bireylerin bazı özellikleri karşılaştırmalı olarak Tablo 1 'de görüldüğü gibi sıralanmaktadır.

Tablo 1. İç ve Dış Kontrol Odaklı Bireylerin Özellikleri

\begin{tabular}{|c|c|}
\hline İç Kontrol Odağı Yapısına Sahip Bireyler & Dış Kontrol Odağı Yapısına Sahip Bireyler \\
\hline $\begin{array}{l}\text { Dendi yeteneklerine güvendikleri için oluşan } \\
\text { baskılara karşı kendilerini daha iyi ifade ederler ve } \\
\text { savunurlar. Buna bağlı olarak dirençli ve } \\
\text { 1srarcıdırlar. } \\
\text { Dir sorunla karşılaştıklarında endişe duymazlar ve } \\
\text { tekrar aynı sorunları yaşamamak için gereken } \\
\text { çözüm yolları ararlar. } \\
\text { Başarısızlıkların nedenin şanstan çok kendi } \\
\text { yaptıkları hatalarda ararlar aynı zamanda elde } \\
\text { ettikleri başarıların kendi yetenek ve } \\
\text { becerilerinden kaynaklandığını düşünürler. } \\
\text { Kendi yaşadıkları ile alakalı sorumlulukları } \\
\text { üstlenirler, kendilerini rahatsı eden kötü durum ve } \\
\text { olayları düzeltmeye çalışırlar. } \\
\text { Kararlarını kendileri aldıkları için bilgiye çok } \\
\text { gereksinim duyarlar. } \\
\text { Çevrelerindeki olaylara pozitif yaklaşırlar. Açık } \\
\text { fikirlidirler ve yapıcı yaklaşımlar sergilerler. } \\
\text { Olaylar karşısında sakin kalıp olayları düzeltme }\end{array}$ & $\begin{array}{l}\text { Yaşamlarındaki olayları şans ve dış koşullara } \\
\text { bağladıkları için boyun eğici ve itaatkârdırlar. } \\
\text { Dolayısıyla dirençsizdirler ve çabuk vazgeçerler. } \\
\text { Yaşadıkları olaylar karşısında yapabilecek bir } \\
\text { şeyleri olmadığını düşündükleri için son derece } \\
\text { kaygılıdırlar. } \\
\text { Başarısızlıklarını şans ve dış koşullara bağladıkları } \\
\text { için sorumluluk almaktan kaçırlar. Başarıyı elde } \\
\text { etmek için gerekli çabayı göstermezler. } \\
\text { Yaşamlarındaki olumlu koşulları artırmaya } \\
\text { çalışırlar diğer yandan olumsuz durumları } \\
\text { düzelmek için çaba göstermezler ve durumu } \\
\text { kabullenmeyi tercih ederler. } \\
\text { Toplum baskıları ve başkalarının dayatmalarına } \\
\text { göre yaşadıkları için bilgiye olan ihtiyaçları çok } \\
\text { fazla değildir. } \\
\text { Çevrelerindeki olaylara karşı daha negatif yaklaşır, } \\
\text { çevre üzerinde etkileri sınırlı olduğu için kaygılı, } \\
\text { kuşkucu ve sinirli davranışlar gösterirler. }\end{array}$ \\
\hline
\end{tabular}


yoluna girerler. $>$ Değişim durumlarında pasif kalırlar.

$>$ Kader üzerinde kontrole sahip olduklarını

düşündükleri için değişism ve gelişime açıktırlar.

Kaynak: (Gangai vd., 2016: 56)

\section{2. İș Stresi Kavramı}

Literatüre bakıldığında stresin birçok farklı tanımının yapıldığı görülmektedir. En genel tanımıyla stres, "Kişiyi, bir ihtiyacından vazgeçmesine veya bir davranışta bulunmasına zorlayan, kişinin kendisinden veya dışarıdan gelen ve genellikle kişide gerilime, sıkıntıya, daralmaya ve çöküntüye yol açan güç" şeklinde tanımlamak mümkündür (Özkalp, vd., 2013: 22-28).

Stres kavramını, çeşitli araştırmacılar farklı şekillerde tanımlamışlardır. Magnuson (1990), bireyin gerçek yaşantısıyla hayal ettikleri ve beklentileri arasındaki farklılıktan kaynaklı tepki; Davis (1982), kişinin hislerinde, düşünme aşamalarında ya da fiziki koşullarda, bireyin kendi çevresi ile mücadele etme gücünü tehdit eden bir korku ve gerilim hâli; Robbins (1996), bireylerin karşılaştıkları şans, sınırlama ya da arzuların belirli olmayan ve önem oluşturan canlı şartlarının sonucu şekillerinde tanımlamışlardır (Soysal, 2009: 18).

İş stresi kavramı ise şahısların yeteneklerindeki eksikliklere, fiziksel ya da psikolojik sebeplere dayalı olarak meydana gelen ve şahısta korku ve gerilim oluşturan durumu ifade etmektedir (Göçeri, 2014: 21). Çalışma durumunda ortaya çıkan iş stresi, çalışanlar için potansiyel bir zorlanmayı da beraberinde getirmektedir (Göçeri, 2014: 21).

İş stresini, çalışma ve çevreyle etkileşim gibi durumlar sonucunda ortaya çıkan gerilim şeklinde de tanımlayabiliriz. Konu ile ilgili yapılan çalışmalarda, iş stresinin, çalışanlar ve yakın çevresi arasındaki etkileşimden kaynaklandığı tespit edilmiştir. Buna göre, çalışma ortamının birey üzerinde oluşturduğu etki ile bireyin iş yapma gücü ve kapasitesi arasında fark olması durumunda bireyin yaşadığı iş stresi artar (Efeoğlu ve Özgen, 2007: 239).

\section{3. İş Performansı Kavramı}

Performans, belirlenen bir zamanda meydana getirilen ürün ya da hizmet miktarı olarak tanımlanmaktadır (Savcı, 2012: 50). Aynı zamanda etkinlik, verim, çıtı vb. kelimelerle aynı anlamda kullanılabilmekte ve şahsın beceri ile moral-motivasyonu arasındaki etkileşimin bir çıktısı olduğu belirtilmektedir (Savc1, 2012: 50).

Performansın, bir işi veya durumu gerçekleştirmek, icra etmek, ifa etmek gibi anlamları da söz konusudur. Sanatsal anlamda, örneğin tiyatrocu için gösteri yapmak, dramatize etmek; bir müzisyen için kullandığı müzik aleti ile veya sözel olarak ezgi oluşturmak anlamlarında kullanılabilmektedir (Özmutaf, 2007: 42). Performans, "belirli şartlarda örgütler tarafından çalışnlardan beklenenlerin yerine getirilme düzeyi veya çalışan bireyin davranış şekli” olarak da ifade edilmektedir ( Bingöl, 2013: 273).

İş performansı ise hedeflenen bir işin ne derecede yapıldığını betimleyen bir kavramdır. Bireysel açıdan bakıldığında iş performansı, organizasyonun hedefine ulaşma çabasına katkı sağlamak amacıyla çalışanın gösterdiği davranışlardır (Sonnentag vd., 2002: 
3). İş performansı, bir ürünün miktarını, niteliğini, zaman ve maliyet etkinliğini önemseyerek yapmak (Smith ve Goddard,2002: 250) anlamına gelmektedir. İş performansı aynı zamanda, çalışanların, onlara verilen belirli, gerçekleştirilebilir ve önemli hedeflere, dönem sonunda belirli kriterlere göre erişip erişmeme durumlarını ifade eder (Yılmaz, 2016: 40). İş performansı, örgütlerin hedeflerine ulaşmasına katkı sağlayan çalışanların ölçülebilir iş sonuçları, eylemleri ve davranışlarıdır (Viswesvaran ve Deniz, 2000).

\section{4. İş Tatmini}

Tatmin, birey tarafından arzu edilen bir olgunun gerçekleşmesinin sağladığı gönül doygunluğu anlamına gelmektedir. Tatmin, ihtiyaçların sağlanması sonucu oluşan mutluluk durumu şeklinde de tanımlanmaktadır (Halsey, 1988: 884). İş tatmini kavramını literatüre kazandıran isim ise 1935 yılında Hopock olmuştur. Hopock, iş tatmininin, psikolojik, fizyolojik ve çevresel faktörlerin bir bileşimi olarak çalışanların "İ̧simden tatmin oluyorum" şeklindeki ifadeleri olduğunu savunmuştur (Çınar ve Karcıoğlu, 2016: 123).

İş görenler, yaşamlarının önemli bir kısmını iş yerlerinde geçirmektedirler. Çalışanların iş yerinde geçirdiği zaman diliminde yaşadıkları tüm duygular, tüm yaşamlarını etkilemekte ve özel yaşamlarında geçirdiği zamanın kalitesini doğrudan etkilemektedir. İş tatmini konusu, iş dünyasında en çok incelenen konulardan biri haline gelmiştir. İş tatmini, iş yaşamında verimliliği etkileyen bir unsur olduğundan iş tatmin seviyeleri araştırılmakta ve yapılan araştırmalar sonucunda iş ortamının daha sağlıklı ve verimli hale gelmesi için gerekli tedbirlerin alınması amaçlanmaktadır (Köse, 2013: 4).

İş tatmini, çalışanın işine karşı sergilediği tutum ve davranışlarla ilgilidir. Bu kavram, iş görenin yaptığı işle alakalı olarak hissettiği pozitif duyguları ifade eder. İşe karşı tutum pozitif ise "İş Tatmini”, negatif ise "İş Tatminsizliğ̣i” ortaya çıkar. İş görenler, yaptıkları işin sonucunda emeklerinin karşıllğını almak ve kendileri ve kişilik yapılarıyla uyumlu bir pozisyonda bulunmak isterler. Çalışan bireyler, yaptıkları iş sonucundaki beklentileri ile kazanımları arasında bir tutarlılık olduğu sürece işlerinden tatmin olurlar (Üçüncü, 2016: 7).

\section{LITARATÜR VE HIPOTEZLER}

Kontrol odağı olarak bilinen ve bireylerin yaşamlarındaki olaylar üzerindeki kontrol derecesi hakkındaki inançlarını yansıtan olgu 50 yıldan fazla bir süredir akademik alanda yapılan çalışmalarla incelenmektedir. Erken dönem araştırmaların sonuçları, kontrol odağının, çalışma hayatı ile ilgili çeşitli çıktıların kilit bir göstergesi olduğunu göstermiştir (Galvin ve diğerleri, 2018:1).

Konu ile ilgili olarak yapılan araştırmalara ve bulgularına bakıldığında, kişilerin kontrol odağı davranışları ile çalışma hayatlarında yaşadıkları tatmin, performans ve stres gibi faktörler arasında bir ilişki olduğu görülmektedir.

Mitchell, Terence ve Charles (1975), Amerika'da bir kamu işletmesinde çalışan bireyler üzerinde anket yöntemi kullanarak bir araştırma gerçekleştirmişlerdir. Yaptıkları araştırmada, iç kontrol odağı yapısına sahip iş görenlerin yönetim pozisyonlarında çalışmayı hedefledikleri ve dış kontrol odaklı bireylere göre iş tatmin seviyelerinin daha yüksek olduğu tespit edilmiştir. 
Fielding ve Gali (1982), dış kontrol odağı yapısına sahip öğretmenlerin yüksek seviyede strese ve tükenmişliğe sahip olduklarını saptamışlardır. Sonuçlara göre öğrenciler hakkında olumsuz tutumda bulunan öğretmenlerin dış denetim odağı seviyelerinin daha yüksek ve tahammül seviyelerinin daha düşük olduğunu ayrıca bu öğretmenlerin stres düzeylerinin daha yüksek olup çok daha fazla tükenmişlik yaşadıklarını tespit etmişlerdir.

Frucot ve Shearon (1991), örneklem olarak Meksika'da faaliyet gösteren işletmelerde görev alan 83 üst düzey yöneticinin alındığı bir araştırma yapmışlardır. Çalışmalarında kontrol odağı ile katılımlı bütçeleme süreci arasındaki ilişkiyi ve bunun yönetsel performans ile iş tatmini üzerindeki etkisini test etmişlerdir. Araştırma sonuçlarına göre kontrol odağının yöneticilerin iş tatmini üzerinde önemli bir etkisi olmadığ 1 ancak iş performansı üzerinde anlamlı ve önemli bir etkisinin bulunduğunu belirlemişlerdir.

Reed, Kratchman ve Strawser (1994), cinsiyet ve kontrol odağının Amerika Birleşik Devletleri'nde faaliyetlerini sürdüren muhasebecilerin örgütsel bağlllık, iş tatmini ve iş değiştirme davranışları üzerindeki gücünü ölçmek amacıyla gerçekleştirdikleri bir çalışmayı yayınlamışlardır. Buna göre, iç kontrol odağı yapısına sahip muhasebecilerin iş tatmini ve örgütsel bağlılık seviyelerinin dış kontrol odağı yapısına sahip muhasebecilere göre daha yüksek olduğu tespit edilmiştir.

Ambulans servisinde görev yapan bireylerin iş doyumu ve denetim odağının işten kaynaklı strese etkisini inceleyen Young ve Cooper (1995), 427 çalışandan topladıkları verileri incelemişlerdir. Çalışma sonucunda iş doyumu düşük bireylerin daha fazla stres yaşadığını, önemli problemlerinin olduğunu ve dış denetim odağı eğilimine sahip olduklarını belirlemişlerdir.

Hyatt ve Prawitt (2001), bağımsız denetim firması çalışanları üzerinde gerçekleştirmiş oldukları çalışmalarında uygun kontrol odağı ve denetim tarzı birleşiminin, denetçinin performansı üzerindeki etkisini ölçmeyi amaç edinmişlerdir. Araştırma sonuçlarına göre iç kontrol odaklı denetçilerin kurumsal bir denetim tarzı olmayan denetim firmalarında daha yüksek performans gösterdikleri; dış kontrol odaklı kişiliğe sahip denetçilerin ise kurumsal denetim anlayışına sahip denetim firmalarında daha yüksek bir performans sergiledikleri belirlenmiştir.

Kirkcaldy, Shephard ve Furnham (2002)'1n Alman yöneticilerden oluşan bir grup üzerinde yaptıkları araştırma sonucunda, dış kontrol odaklı kişilerin, iç kontrol odaklı kişilere göre daha yüksek iş stresi, daha düşük iş tatmini ve daha zayıf fiziksel veya ruhsal sağlıklarının olduğu tespit edilmiştir.

İç denetçilerin performans ve iş tatmini düzeyleri ile kişilik yapıları arasında bir ilişki olup olmadığını inceleyen Patten (2005), çalışmasında ABD'de faaliyet gösteren 6 işletmedeki 50 iç denetçinin kişilik yapılarını kontrol odağı ölçeğini kullanarak belirlemiştir. Buna göre iç kontrol odaklı iç denetçilerin diş kontrol odaklı denetçilere göre daha üst seviyelerde performans gösterdiklerini tespit edilmiştir.

Candangil ve Ceyhan (2006), Bursa'da 11 lisede toplam 2045 öğrenci üzerine yaptıkları araştırma sonucunda, karar verme aşamasında iç kontrol odaklı öğrencilerin özsaygı 
seviyelerinin diğerlerine göre daha yüksek ve stres düzeylerinin ise daha düşük olduğunu belirlemişlerdir.

Demirkol (2006), Mersin Barosu'na kayıtlı 57'si bayan 103'ü erkek toplam 160 avukat üzerinde "Avukatlarda İş Doyumu, Tükenmişlik ve Denetim Odağının Bazı Demografik Değişskenler Bağlamında İncelenmesi” konulu araştırma yapmıştır. İlgili araştırmada dış kontrol odağı yapısına sahip avukatların düşük bir iş tatmin seviyesinde yaşadığı, iç kontrol odağı yapısına sahip bayan avukatların iş tatmin ve kişisel başarı düzeylerinin yüksek olduğu bunun yanında düşük düzeyde de tükenmişlik yaşadıkları belirtilmiştir.

Chen ve Silverstone (2008), Tayvan'da aktif olarak faaliyet gösteren 209 meslek mensubunun kontrol odağı ile stres, iş tatmini ve performansı arasındaki ilişkiyi incelemişlerdir. Sonuç olarak iç kontrol odağına sahip bireylerin, diş kontrol odağına sahip bireylerden daha düşük iş stresine ve daha yüksek iş performansı ve tatminine sahip oldukları ortaya çıkmıştır.

Çaylı (2013), araştırmasında, çalışanların genel iş tatmini düzeyleri ile kontrol odaklı olmaları arasında anlamlı bir ilişkinin olduğunu tespit etmiştir. İç kontrol odaklılık özelliği gösteren çalışanların iş tatmin düzeyleri de daha yüksek çıkmıştır.

Tanç (2016), çalışmasında, Kayseri'de 132 muhasebe meslek mensubunun kontrol odağı davranışları ile iş tatmini ve performansı düzeyleri arasındaki ilişkiyi incelemiştir. Araştırma bulgularına göre, kontrol odağının iş tatmini ve iş performansı düzeyinin tahmin edilmesinde kullanılabileceği ortaya çıkmıştır. Araştırmada ayrıca iç kontrol odaklı meslek mensuplarının diş kontrol odaklı meslek mensuplarına göre, iş tatmin ve iş performansı seviyelerinin daha yüksek olduğu tespit edilmiştir.

Literatürde yer alan ve yukarıda bir bölümüne yer verilmeye çalışılan çalışmaların bulgularından hareketle bu çalışma kapsamında belirlenen ve geçerliliği araştırılacak olan hipotezler aşağıdaki gibidir:

H1: Dış kontrol odaklı muhasebe meslek mensuplarl iç kontrol odaklı muhasebe meslek mensuplarına göre daha fazla iş stresi yaşarlar.

H2: Dış kontrol odakl muhasebe meslek mensuplarl iç kontrol odaklı muhasebe meslek mensuplarına göre işlerinden daha az tatmin olurlar.

H3: Dış kontrol odaklı muhasebe meslek mensuplarının iç kontrol odakl muhasebe meslek mensuplarına göre iş performansları daha düşüktür.

H4: Muhasebe meslek mensupları açısından iç kontrol odaklılığı iş tatmini üzerinde pozitif etkiye sahiptir.

H5: Muhasebe meslek mensuplarl açısından dış kontrol odaklılığı iş tatmini üzerinde negatif etkiye sahiptir.

H6: Muhasebe meslek mensupları açısından iç kontrol odaklılı̆̆ işs performansı üzerinde pozitif etkiye sahiptir. 
H7: Muhasebe meslek mensupları açısından dış kontrol odaklılı̆̆ iş performansı üzerinde negatif etkiye sahiptir.

H8: Muhasebe meslek mensupları açısından iç kontrol odaklılı̆̆l, işs stresi üzerinde negatif etkiye sahiptir.

H9: Muhasebe meslek mensupları açısından dış kontrol odaklıliğg, iş stresi üzerinde pozitif etkiye sahiptir.

\section{VERİ VE YÖNTEM}

Tablo 2'de bu araştırmanın evrenine ilişkin bilgiler yer almaktadır. Çalışmanın yapıldı̆̆ı tarih itibari ile Türkiye'de 8.791 SM, 96.785 SMM ve 4.758 YMM olmak üzere toplamda 110.334 meslek mensubu faaliyet göstermektedir.

Tablo 2. Türkiye'de Faaliyet Gösteren Meslek Mensuplarının Unvanlarına Göre Dağglımı

\begin{tabular}{cccc}
\hline Serbest Muhasebeci & $\begin{array}{c}\text { Serbest Muhasebeci ve } \\
\text { Mali Müșavir }\end{array}$ & Yeminli Mali Müşavir & Toplam \\
\hline 8.791 & 96.785 & 4.758 & 110.334
\end{tabular}

Kaynak: (TÜRMOB, 2017)

Araştırmada $p=0,50$ ve $q=0,50$ olarak belirlenmiş ve hoşgörü miktarı $d=+0,05$ kabul edilerek, \%95 güven düzeyinde örneklem büyüklüğü belirlenmiştir. \% 95'lik güven aralığ1 düzeyine göre örneklem büyüklügüün̈ 383 olması yeterli görülmektedir (Krejcie ve Morgan, 1970; Yazıcıŏ̆lu ve Erdoğan, 2004:50).

Örneklem sayısı belirlendikten sonra Türkiye'de çeşitli bölgelerde faaliyet gösteren 399 meslek mensubuna anket uygulaması yapılmıştır. Örnekleme ulaşmada kolayda ve kartopu örnekleme yöntemleri kullanılmıştır. Ancak araştırmaya katılan muhasebe meslek mensuplarından elde edilen ve eksik ya da gelişigüzel cevaplanan anketler çıkarıldıktan sonra bilimsel amaçlara hizmet eden kullanılabilir 178 anket analiz kapsamına alınmıştır.

Anket formlarının meslek mensuplarına ulaştırılması hususunda; Türkiye'de faaliyette bulunan SMMM odaları, meslek mensupları, akademisyenler ve ilimiz meslek mensuplarından yardım alınmıştır.

Araştırmadaki verilerin tamamı anket yöntemi kullanılarak, Türkiye'de aktif olarak faaliyet gösteren SM, SMMM ve YMM unvanlarına sahip meslek mensuplarına uygulanarak toplanmıştır. Araştırmaya konu olan anket, kişiliğin bir boyutu olarak kabul edilen kontrol odağının, muhasebe meslek mensuplarının iş tatmini, iş stresi ve iş performansları düzeylerini nasıl etkilediğini incelemeye yönelik olarak hazırlanmıştır. Anket formu beş bölümden (demografik özellikler, kontrol odağı ölçeği, stres, tatmin, performans ölçekleri) meydana gelmektedir.

Muhasebe meslek mensuplarının kişilik yapılarını belirlemek için Rotter (1966)'ın geliştirdiği 29 maddelik Kontrol Odağı Ölçeği, iş stresi seviyesini ölçmek amacıyla Price 
(2001) tarafından geliştirilen iş stresi ölçeği, iş tatmini seviyesini ölçmek amacıyla Price (2001) tarafından geliştirilen iş tatmini ölçeği ve iş performansı seviyesini ölçmek amaciyla Yousef (2000) tarafından geliştirilen iş performansı ölçeği kullanılmıştır.

Anketler, büro sahibi olan ya da herhangi bir kurumda çalışan SM, SMMM ve YMM unvanlı muhasebeciler üzerine uygulanmıştır. Verilerin analizinde SPSS 20 istatistik programından yararlanılmıştır. Analizlerde frekans analizleri, tanımlayıcı istatistikler, faktör analizi, güvenirlik analizi, bağımsız gruplar t testi, korelasyon analizi ve basit doğrusal regresyon analizi yöntemleri kullanılmıştır.

\section{BULGULAR}

\subsection{Demografik Özellikler}

Yapılan araştırma kapsamında ankette öncelikle katılımcı meslek mensuplarının demografik özelliklerini belirlemek amaciyla cinsiyet, yaş, öğrenim durumu, mesleki unvan ve mesleki deneyimleri ile ilgili bulgularına bakılmıştır. Sonuçlar Tablo 3' te özetlenmiştir.

Tablo 3. Katılımcıların Demografik Özellikleri

\begin{tabular}{|c|c|c|c|}
\hline & & $\mathbf{f}$ & $\%$ \\
\hline \multirow{3}{*}{ Cinsiyet } & Erkek & 131 & 73,6 \\
\hline & Kadın & 47 & 26,4 \\
\hline & Toplam & 178 & 100,0 \\
\hline & & $\mathbf{f}$ & $\%$ \\
\hline \multirow{6}{*}{ Yaş } & $20-30$ & 16 & 9,0 \\
\hline & $31-40$ & 64 & 36,0 \\
\hline & $41-50$ & 68 & 38,1 \\
\hline & 50 ve Üzeri & 30 & 16,9 \\
\hline & Toplam & 178 & 100,0 \\
\hline & & $\mathbf{f}$ & $\%$ \\
\hline \multirow{8}{*}{ Öğrenim Durumu } & İlkokul & 1 & ,6 \\
\hline & Ortaokul & 1 & ,6 \\
\hline & Lise & 17 & 9,6 \\
\hline & Ön Lisans & 9 & 5,1 \\
\hline & Lisans & 130 & 73,0 \\
\hline & Yüksek Lisans & 18 & 10,1 \\
\hline & Doktora & 2 & 1,1 \\
\hline & Toplam & 178 & 100,0 \\
\hline & & $\mathbf{f}$ & $\%$ \\
\hline \multirow{4}{*}{ Mesleki Unvan } & Serbest Muhasebeci & 16 & 9,0 \\
\hline & Serbest Muhasebeci Mali Müşavir & 158 & 88,8 \\
\hline & Yeminli Mali Müşavir & 4 & 2,2 \\
\hline & Toplam & 178 & 100,0 \\
\hline & & $\mathbf{f}$ & $\%$ \\
\hline \multirow{7}{*}{ Mesleki Deneyim } & $1-5 Y_{11}$ & 22 & 12,4 \\
\hline & 6-10 Y1l & 31 & 17,4 \\
\hline & 11-15 Y1l & 25 & 14,0 \\
\hline & $16-20 Y_{1}$ & 42 & 23,6 \\
\hline & $21-25 Y_{11}$ & 22 & 12,4 \\
\hline & 26 Y1l Üzeri & 36 & 20,2 \\
\hline & Toplam & 178 & 100,0 \\
\hline
\end{tabular}


Tablo 3'e göre katılımcıların \%73,6'sı erkek, \%26,4'ü kadındır. Bu sonuç kadınların erkeklere göre muhasebe mesleğini daha az tercih ettiklerini gösterebilir. Katılımcıların \%9'u 20-30 yaş, \%36's1 31-40 yaş, \%38,1'i 41-50 yaş, \%16,9'u 50 ve üzeri yaş grubundadır. Katılımcilardan \%0,6's1 ilkokul, \%0,6's1 ortaokul, \%9,6's1 lise, \%5,1'i ön lisans, \% 73'ü lisans, \%10,1'i yüksek lisans, \%1,1'i doktora seviyesinde öğrenim durumuna sahiptir. Katılımcilardan \%9'u Serbest Muhasebeci, \%88,8'i Serbest Muhasebeci Mali Müşavir, \%2,2'si Yeminli Mali Müşavir unvanına sahiptir. Katılımcıların mesleki unvanlarına göre dağılımında çoğunluğun serbest muhasebeci mali müşavir olduğu göze çarpmaktadır. Kat1lımcilardan \%12,4'ü 1-5 y11, \%17,4'si 6-10 y11, \%14'ü 11-15 y11, \%23,6's1 16-20 y1l, $\% 12,4$ 'ü 21-25 y1l ve \%20,2'si 26 ve üzeri y1l deneyimine sahiptir.

\subsection{Katılımcıların Kontrol Odağı İle İlgili Bulguları}

Muhasebe meslek mensuplarının kişilik yapılarını belirlemek amacıyla, 29 maddeli “Kontrol Odağı Ölçeği” kullanılmıştır. Her madde, seçime zorlayan cevaplama türünde ikişer seçeneği kapsamaktadır. Katılımcılara yöneltilen 1.,8.,14.,19.,24. ve 27. sorular dolgu olarak yerleştirilmiş ve katılımcılar tarafından bu sorulara verilen cevaplar puanlamaya dahil edilmemiştir. Puanlama sonucunda 13 ve üzeri puan alan katılımcılar dış kontrol odaklı, 12 ve altı puan alanlar iç kontrol odaklı olarak kategorize edilmiştir.

Tablo 4: Kontrol Odağı

\begin{tabular}{lccc}
\hline & & f & \% \\
\hline \multirow{3}{*}{ Kontrol Odağı } & İç Kontrol Odağı & 143 & 80,3 \\
& Dış Kontrol Odağ & 35 & 19,7 \\
& Toplam & $\mathbf{1 7 8}$ & $\mathbf{1 0 0 , 0}$ \\
\hline
\end{tabular}

Tablo 4'e göre, 178 meslek mensubunun \%80,3'ünün iç kontrol odağ1, \%19,7'sinin dış kontrol odağı yapısına sahip olduğu görülmektedir. Çalışmaya katılan meslek mensuplarının büyük bir çoğunluğunun iç kontrol odaklı bireyler olduğu saptanmıştır.

\subsection{Faktör Analizi}

Faktör analizi, verilerin uygunluğu için yapılan Kaiser-Meyer-Olkin(KMO) katsayısı ve Barlett küresellik testiyle sonuçlanan bir analiz türüdür. KMO değeri 0-1 arasında değer almalıdır. Bu değer 1'e ne kadar yakın olursa araştırma analizine konu olan veri seti faktör analizine o kadar uygun olmaktadır. Barlett testi ise; değişkenler arasındaki korelasyonunun yüksek olup olmadığını ölçmektedir. "Evrende yer alan değişkenler arasında korelasyon yoktur ya da korelasyon matrisi birim matristir." şeklinde kurulan hipotez reddedildiğinde değişkenlerin faktör analizine uygun olduğu sonucuna varılmaktadır (Yüksel, 2013: 27).

Değişkenler arası ilişkilerin ve bunların muhasebe meslek mensuplarının kontrol odağıyla olan ilişkisinin araştırılması için araştırmada kullanılan tüm değişkenlere ait faktör yapısının test edilmesi gerekmektedir. Bu amaçla tüm değişkenlerin faktör yapısının belirlenmesi için çalışmada kullanılan değişkenlere faktör analizi yapılmıştır. Araştırmada kullanılan ölçekler sırasıyla faktör analizine tutulmuştur. İlgili ölçekler ve ölçeklerde yer alan ifadeler çalışmanın "Ekler” bölümünde verilmiştir. 


\subsection{1. İş Stresi Ölçeği}

Çalışmada ilk olarak iş stresi ölçeğiyle alakalı olarak gerçekleştirilen faktör analiziyle elde edilen sonuçlara yer verilmiştir.

Tablo 5. İş Stresi Ölçeği Kaiser-Meyer-Olkin (KMO) ve Bartlett Test Sonuçları

\begin{tabular}{lll}
\hline Kaiser-Meyer-Olkin Örneklem Yeterliliği & & .804 \\
\hline \multirow{3}{*}{ Bartlett's Küresellk Testi } & Ki-kare değeri & 1822.125 \\
\cline { 2 - 3 } & Serbestlik derecesi & 210 \\
\cline { 2 - 3 } & $p$ & .000 \\
\hline
\end{tabular}

Tablo 5'te anket sorularından elde edilen veri seti ile yapılan analiz sonucunda KMO test değeri 0,804 çıkmıştır. Bu durum veri setinin faktör analizi testi için elverişli olduğunu göstermektedir. Ayrıca yine değişkenler arasındaki korelasyonu ifade eden Bartlett testinin değeri 0,05 anlamlılık düzeyinde faktör analizi için anlamlı çıkmıştır. Yapılan testlerin sonucunda analiz sonuçlarının anlamlı olduğunu söyleyebiliriz.

Tablo 6. İş Stresi Ölçeği Faktör Analiz Sonuçları

\begin{tabular}{|c|c|c|c|c|c|}
\hline $\begin{array}{l}\text { İş Stresi Ölçek } \\
\text { Maddeleri }\end{array}$ & $\begin{array}{l}\text { Faktör-1 İş } \\
\text { Yükü }\end{array}$ & $\begin{array}{c}\text { Faktör-2 } \\
\text { Roller Arası } \\
\text { Çatışma }\end{array}$ & $\begin{array}{c}\text { Faktör-3 Rol } \\
\text { Belirsizliği }\end{array}$ & $\begin{array}{c}\text { Faktör-4 } \\
\text { Kaynak } \\
\text { Yetersizliği }\end{array}$ & $\begin{array}{c}\text { Faktör-5 Kaynak } \\
\text { Yetersizliği-2 }\end{array}$ \\
\hline \multicolumn{6}{|l|}{ İŞSTR 16} \\
\hline \multirow{2}{*}{\multicolumn{6}{|c|}{$\begin{array}{l}\text { İSSSTR } 15 \\
\text { İSSTR } 9\end{array}$}} \\
\hline & & & & & \\
\hline İŞSTR 17 & ,852 & & & & \\
\hline İSSTR 19 & 814 & & & & \\
\hline İŞSTR 6 & ,805 & & & & \\
\hline İSSSTR 10 & ,802 & & & & \\
\hline İSSSTR 8 & ,781 & & & & \\
\hline İŞSTR 7 & ,765 & & & & \\
\hline İŞSTR 20 & ,701 & ,841 & & & \\
\hline İŞSTR 21 & 606 & 829 & & & \\
\hline İŞSTR 22 & ,478 & ,804 & & & \\
\hline İŞSTR 4 & &, 520 & & & \\
\hline İȘSTR 5 & &, 505 & & & \\
\hline İŞSTR 6 & & ,434 & & & \\
\hline İSSTR 1 & & & ,848 & & \\
\hline İŞSTR 2 & & & ,823 & & \\
\hline İSSSTR 13 & & & & ,835 & \\
\hline İSSSTR 14 & & & & 750 & \\
\hline İŞSTR 11 & & & & & ,835 \\
\hline İSSTR 12 & & & & &, 750 \\
\hline
\end{tabular}

Yapılan analiz sonucunda çalışmanın iş stresi ölçeğinin 5 faktörden oluştuğu görülmektedir (Tablo 6). En uygun faktör yapısına ulaşmak için yapılan varimax dönüşümünün sonucunda 1 adet ifade (İş stresi ölçeğinde 3. ifade) analiz dışında birakılmıştır. Tablo 6' da görüldüğü üzere faktör yükleri ayrışmıştır. Bu, sorularla ilişkili herhangi bir problemin olmadığını göstermektedir. 5 adet faktörle açıklanan toplam varyans \%64,50'dir. 


\subsection{2. İş Tatmini Ölçeği}

Tablo 7'de anket sorularından elde edilen veri seti ile yapılan analiz sonucunda KMO test değeri 0,746 çıkmıştır. Elde edilen veri setinin faktör analizi için elverişli olduğunu göstermektedir. Ayrıca yine değişkenler arasındaki korelasyonu ifade eden Bartlett testinin değeri 0,05 anlamlılık düzeyinde faktör analizi için anlamlı çıkmıştır. Yapılan testlerin sonucunda analiz sonuçlarının anlamlı olduğunu söyleyebiliriz.

Tablo 7: İş Tatmini Ölçeği Kaiser-Meyer-Olkin (KMO) ve Bartlett Test Sonuçları

\begin{tabular}{lcc}
\hline \multicolumn{2}{c}{ KMO Örneklem Yeterliliği } & \multicolumn{1}{c}{, 746} \\
\cline { 2 - 3 } Bartlett's Küresellk Testi & Ki-kare değeri & 557,302 \\
\cline { 2 - 3 } & Serbestlik derecesi & 15 \\
\cline { 2 - 3 } & $\mathrm{P}$ & .000 \\
\hline
\end{tabular}

Tablo 8'de anket sorularından elde edilen veri seti ile yapılan analiz sonucunda KMO test değeri 0,746 çıkmıştır. Elde edilen veri setinin faktör analizi için elverişli olduğunu göstermektedir. Ayrıca yine değişkenler arasındaki korelasyonu ifade eden Bartlett testinin değeri 0,05 anlamlılık düzeyinde faktör analizi için anlamlı çıkmıştır. Yapılan testlerin sonucunda analiz sonuçlarının anlamlı olduğunu söyleyebiliriz.

Tablo 8. İş Tatmini Ölçeği Faktör Analiz Sonuçları

\begin{tabular}{ccc}
\hline İş Tatmini Ölçek Maddeleri & Faktör-1 İş Memnuniyeti & Faktör-2 İşten Ayr1lma Niyeti \\
\hline İŞT2 &, 902 & \\
IŞ̧T3 &, 836 &, 929 \\
İŞT1 &, 834 &, 917 \\
İŞT5 & &, 349 \\
ISŞT4 & & İ̧6 \\
\hline Açıklanan Toplam Varyans: \%77,287; İŞT : İş Tatmini Ölçeği; Rotasyon Yöntemi: Varimax \\
\hline
\end{tabular}

Yapılan analiz sonucunda çalışmanın iş tatmini ölçeğinin 2 faktörden oluştuğu görülmektedir. Tabloda da görüldüğü üzere faktör yükleri ayrışmıştır. Bu, sorularla ilişkili herhangi bir problemin olmadığını göstermektedir. 2 adet faktörle açıklanan toplam varyans $\% 77.287^{\prime}$ dir.

\subsection{3. İş Performansı Ölçeği}

Anket sorularından elde edilen veri seti ile yapılan analiz sonucunda Tablo 9'a göre KMO test değeri 0,755 çıkmıştır. Elde edilen veri setinin faktör analizi için elverişi olduğunu göstermektedir. Ayrıca yine değişkenler arasındaki korelasyonu ifade eden Bartlett testinin değeri 0,05 anlamlılık düzeyinde faktör analizi için anlamlı çıkmıştır. Yapılan testlerin sonucunda analiz sonuçlarının anlamlı olduğunu söyleyebiliriz. 
Tablo 9. İş Performansı Ölçeği Kaiser-Meyer-Olkin (KMO) ve Bartlett Test Sonuçları

\begin{tabular}{lcc}
\hline \multicolumn{2}{c}{ Kaiser-Meyer-Olkin Örneklem Yeterliliği } &, 755 \\
\cline { 2 - 3 } Bartlett's Küresellk Testi & Ki-kare değeri & 338,545 \\
\cline { 2 - 3 } & Serbestlik derecesi & 6 \\
& $p$ & .000 \\
\hline
\end{tabular}

Yapılan analiz sonucunda çalışmanın iş performansı ölçeğinin tek faktörden oluştuğu görülmüştür. Tabloda 10'da faktör yükleri ifade edilmiştir. Bu durum, maddelerin ölçülmek istenen olguyu tek bir faktör altında ölçebildiğinin bir göstergesidir. Açıklanan toplam varyans ise \%65. 842 'dir.

Tablo 10: İş Performansı Ölçeği Faktör Analiz Sonuçları

\begin{tabular}{cc}
\hline İş Performansı Ölçek Maddeleri & Faktör-1 Öz Değerlendirme \\
\hline IŞSP2 &, 904 \\
IŞP1 &, 903 \\
IŞP4 &, 868 \\
IŞP3 &, 497 \\
\hline Açıklanan Toplam Varyans: \%65,842; İŞP :İş Performansı Ölçeği; Rotasyon Yöntemi: Varimax
\end{tabular}

\subsection{Normal Dağılıma Uygunluk Analizleri}

Parametrik hipotez testlerinin yapılabilmesi için verilerin öncelikle normal dağılıma sahip olması gerekir. Çalışmada bu amaçla tanımlayıcı istatistiklerden Basıklık (Kurtosis) Çarpıklık (Skewness) değerlerine bakılmıştır.

Çarpıklık ve Basıklık normal dağılımda sıfır olarak varsayılır. Negatif ise sağa, pozitif ise sola çarpıktır. Basıklık' ta negatif değer basık, pozitif değer ise dikliği ifade eder. Çarpıklık ve Basıklık değerlerinin $\pm 1,5$ (Tabachnick ve Fidell, 2013) veya \pm 2 (George ve Mallery, 2010) yer alması normal dağılım için yeterli kabul edilir. Tablo 11'e göre bu değerlerin söz konusu aralıklarda yer aldığı görülmektedir.

Tablo 11. Ölçeklere İlişkin Tanımlayıcı İstatistikler

\begin{tabular}{ccccccc}
\hline & $\mathbf{N}$ & Ortalama & \multicolumn{2}{c}{ Çarpıklı } & \multicolumn{2}{c}{ Basıklık } \\
\hline \multirow{2}{*}{ İş Performansı } & \multirow{2}{*}{178} & \multirow{2}{*}{5.7711} & İstatistik & Std.Hata & İstatistik & Std.Hata \\
\cline { 4 - 7 } & & &,- 623 &, 182 &,- 083 &, 362 \\
\multirow{2}{*}{ İş Tatmini } & \multirow{2}{*}{178} & \multirow{2}{*}{3,9991} & İstatistik & Std.Hata & İstatistik & Std.Hata \\
& \multirow{2}{*}{ İş Stresi } & \multirow{2}{*}{178} &,- 823 &, 182 & 1,902 &, 362 \\
& \multirow{2}{*}{3,1070} & İstatistik & Std.Hata & İstatistik & Std.Hata \\
& & &,- 393 &, 182 &, 650 &, 362 \\
\hline
\end{tabular}

\subsection{Güvenirlik Analizi}

Araştırmada kullanılan ölçeklerle ilgili olarak geçerlilik ve güvenirlik analizleri gerçekleştirilmiştir. Ankette yer alan ölçeklerin geçerliliği ve güvenirliği için Cronbach's 
Alpha testi uygulanmıştır. Cronbach Alfa katsayısının değerlendirilmesinde kullanılan değerlendirme ölçütü; $0,00 \leq \mathrm{a}<0,40$ ise ölçek güvenilir değildir. $0,40 \leq \mathrm{a}<0,60$ ise ölçek düşük güvenirliktedir. $0,60 \leq \mathrm{a}<0,80$ ise ölçek oldukça güvenilirdir. $0,80 \leq \mathrm{a}<1,00$ ise ölçek yüksek derecede güvenilirdir şeklinde değerlendirilmiştir (Özdamar, 2002:673).

Tablo 12. Ölçeklendirilmiş Tüm Sorular İçin Güvenilirlik Analizi Sonuçları

\begin{tabular}{cc}
\hline Güvenirlik Analizi & Cronbach's Alpha \\
\hline İş Stresi Ölçeğinin Güvenilirliği &, 816 \\
İş Tatmini Ölçeğininin Güvenilirliğ̀i &, 831 \\
İş Performansı Ölçeğininin Güvenilirliği &, 778 \\
\hline
\end{tabular}

Tablo 12 incelendiğinde; ankette yer alan ölçeklerin Cronbach Alpha $(\alpha)$ test istatistiği değerlerinin oldukça güvenilir değerler arasında yer aldığı görülmektedir.

\subsection{Hipotez Testleri ve Sonuçların Yorumlanması}

Çalışmanın bu bölümünde, Bağımsız Örneklem t Testi, Korelasyon Analizi ve Basit Doğrusal Regresyon Analizi yöntemleri kullanılarak elde edilen hipotez testi sonuçlarına yer verilmiştir. İlk üç hipotezin test edilmesi amacıyla bağımsız örneklem t testi kullanılmış olup sonrasında regresyon analizi öncesi değişkenlerin birbirleriyle olan ilişkilerinin ortaya konması ve anlaşılması amacıyla korelasyon analizi sonucu oluşan Pearson korelasyon katsayılarına bakılmıştır. Test edilecek ilk hipotezler aşağıdaki gibidir:

H1: Dış kontrol odakl muhasebe meslek mensupları iç kontrol odakl muhasebe meslek mensuplarına göre daha fazla iş stresi yaşarlar

H2: Dış kontrol odakl muhasebe meslek mensupları iç kontrol odakl muhasebe meslek mensuplarına göre işlerinden daha az tatmin olurlar.

H3: Dış kontrol odakl muhasebe meslek mensuplarının iç kontrol odakl muhasebe meslek mensuplarına göre iş performansları daha düşüktür.

\subsubsection{Bağımsız Örneklem t Testi Sonuçları}

İç ve diş kontrol odaklı bireylerin iş stresi, iş tatmini ve iş performansı ortalamaları arasındaki farkların anlamlılığını ölçmek üzere "Bağımsız Örneklem t Testi” yapılmıştır. Elde edilen sonuçlar, araştırmaya katılan 178 kişinin \%80' inin (143 kişi) iç, \%20'sinin (35 kişi) ise dış kontrol odaklı olduklarını ortaya koymaktadır.

H1 hipotezinin test edilmesi amacıyla yapılan bağımsız gruplar t testi sonuçları Tablo 13 'te görüldüğü gibidir. Tablo 13 'e göre katılımcıların, iş stresi düzeylerinde iç ve dış kontrol odaklı bireyler olup olmamalarına göre anlamlı bir farklılığın olduğu saptanmıştır. $(p=0,024<0.05)$. İç kontrol odaklı grubun iş stresi puan ortalaması 3,07 , diş kontrol odaklı grubun iş stresi puan ortalaması 3,25 bulunmuştur. Dolayısıyla H1 hipotezi doğrulanmıştır. 
Tablo 13. İş Stresi Ölçeği Puanları Açısından t Testi Analizi Sonuçları

\begin{tabular}{|c|c|c|c|c|c|c|}
\hline Boyut & $N$ & Ortalama & ss & $F$ & $t$ & $p$ \\
\hline İş Stresi & & & & 1,683 & $-2,057$ &, $024 *$ \\
\hline $\begin{array}{l}\text { İç Kontrol } \\
\text { Odağ1 }\end{array}$ & 143 & 3,0725 & 46768 & & & \\
\hline $\begin{array}{l}\text { Diş Kontrol } \\
\text { Odağ } 1\end{array}$ & 35 & 3,2481 & ,38354 & & & \\
\hline
\end{tabular}

H2 hipotezinin test edilmesi amacıyla yapılan bağımsız gruplar t testi sonuçları Tablo 14 ' de görüldüğü gibidir. Tablo 14'e göre katılımcıların iş tatmini düzeylerinde iç veya diş kontrol odaklı bireyler olup olmamalarına göre anlamlı bir farklılığın olduğu saptanmıştır. $(p=0,012<0.05)$. İç kontrol odaklı grubun iş tatmini puan ortalaması 4,08 , diş kontrol odaklı grubun iş tatmini puan ortalaması 3,66 bulunmuştur. Dolayısıyla H2 hipotezi doğrulanmıştır.

Tablo 14. İş Tatmini Ölçeği Puanları Açısından T Testi Analizi Sonuçları

\begin{tabular}{ccccccc}
\hline Boyut & $\boldsymbol{N}$ & Ortalama & $\boldsymbol{s s}$ & $\boldsymbol{F}$ & $\boldsymbol{t}$ & $\boldsymbol{p}$ \\
\hline İș Tatmini & & & & 1,799 & 2,919 &, 012 \\
\hline $\begin{array}{c}\text { İç Kontrol } \\
\text { Odağ }\end{array}$ & 143 & 4,0804 &, 72239 & & & \\
$\begin{array}{c}\text { Diş Kontrol } \\
\text { Odağ } 1\end{array}$ & 35 & 3,6667 &, 86319 & & & \\
\hline${ }^{*} p 0,05$ & & & & & & \\
\hline
\end{tabular}

H3 hipotezinin test edilmesi amacıyla yapılan bağımsız gruplar t testi sonuçları Tablo $15^{\prime}$ te görüldügü gibidir. Tablo $15^{\prime}$ 'e göre katılımcıların iş performansı düzeylerinde iç veya dış kontrol odaklı bireyler olup olmamalarına göre anlamlı bir farklılık saptanamamıştır $(p=0,731>0.05)$. İç kontrol odaklı grubun iş performansı puan ortalamas1 5,78 , diş kontrol odaklı grubun iş performansı puan ortalaması 5,74 bulunmuştur. Dolayısıyla H3 hipotezi doğrulanamamıştır.

Tablo 15: İş Performansı Ölçeği Puanları Açısından T Testi Analizi Sonuçları

\begin{tabular}{ccccccc}
\hline \multicolumn{1}{c}{ Boyut } & $\boldsymbol{N}$ & Ortalama & $\boldsymbol{s S}$ & $\boldsymbol{F}$ & $\boldsymbol{t}$ & $\boldsymbol{p}$ \\
\hline İş Performans1 & & & & 1,128 &, 303 &, 731 \\
\hline İ̧ Kontrol Odağ1 & 143 & 5,7797 &, 79749 & & & \\
D̊ş Kontrol Odağ 1 & 35 & 5,7357 &, 64153 & & & \\
\hline${ }^{*} p<0,05$ & & & & & \\
\hline
\end{tabular}

Tablo 15'e göre, iç kontrol odaklı grubun iş performansı puan ortalaması $(X=5,78)$, dış kontrol odaklı grubun iş performansı puan ortalaması $(X=5,73)$ olarak hesaplanmıştır. Son olarak ise; katılımcıların iş performansı düzeylerinin beklenilenin aksine kontrol odağ1 yapılarına göre farklılaşmadığı belirlenmiştir $(p=0,731 ;>0,05)$. 


\subsubsection{Korelasyon Analizi}

Korelasyon analizinde iki ve daha fazla değişken arasındaki ilişkinin yönünün, gücünün veya derecesinin hesaplanması söz konusudur. Tablo16'ya göre kontrol odağı puanı ile iş stresi $(r=0.167 ; p=0,026<0.05)$ arasında zayıf ancak pozitif ve anlamlı bir ilişki görülmekte yani meslek mensuplarının kontrol odağı puanları arttıkça (meslek mensupları dış kontrol odaklı bireye doğru yaklaştıkça) bireylerin iş stresi düzeyleri de artmaktadır. $\mathrm{Bu}$ durum H1 hipotezini desteklemektedir. Kontrol odağı puanı ile iş tatmini puanı arasında ise $(r=-0.265 ; p=, 000<0.001)$ anlamlı ve ters yönlü bir ilişki vardır. Yani meslek mensuplarının kontrol odağı puanları arttıkça (meslek mensupları dış kontrol odaklı bireye doğru yaklaştıkça) meslek mensuplarının iş tatmini azalmaktadır. $\mathrm{Bu}$ durum $\mathrm{H} 2$ hipotezini desteklemektedir.

Tablo 16'e göre, kontrol odağı puanı ile iş performansı $(r=-0.059 ; p=0,435>0.05)$ arasında istatistiksel olarak anlamlı olmayan ilişki bir ilişki vardır. Elde edilen sonuca göre beklenildiği gibi kontrol odağı ile iş performansı arasında bir ilişki bulunamamıştır.

Tablo 16: Değişkenler Arası Korelasyon Analizi

\begin{tabular}{|c|c|c|c|c|c|}
\hline \multicolumn{2}{|l|}{ Ölçekler } & Kontrol Odağı & İş Stresi & İş Tatmini & İş Performansı \\
\hline \multirow{2}{*}{ Kontrol Odağı } & $r$ & 1 &, $167^{* *}$ &,$- 265^{* *}$ &,- 059 \\
\hline & $p$ & & ,026 &, 000 & ,435 \\
\hline \multirow{2}{*}{ İş Stresi } & $r$ & $167^{\text {*** }}$ & 1 &,$- 314^{* * *}$ &,$- 157^{\text {** }}$ \\
\hline & $p$ &, 026 & & ,000 & ,036 \\
\hline \multirow{2}{*}{ İş Tatmini } & $r$ &,$- 265^{* *}$ &,$- 314^{* *}$ & 1 & $316^{* * *}$ \\
\hline & $p$ &, 000 &, 000 & &, 000 \\
\hline \multirow{2}{*}{ İş Performansı } & $r$ &,- 059 &,$- 157^{* *}$ &, $316^{* *}$ & 1 \\
\hline & $p$ & ,435 & ,036 & ,000 & \\
\hline
\end{tabular}

Tablo 16' da ifade edilen Korelasyon katsayısı (r), iki değişken arasındaki ilişkinin ölçüsüdür ve -1 ve +1 arasında değişim gösterir .

\subsubsection{Regresyon Analizi ve Hipotezlerin Testi}

$\mathrm{Bu}$ bölümde bağımsız değişkenlerin bağımlı değişken üzerindeki etkisini ve etkinin derecesini ölçek için kullanılan basit doğrusal regresyon analiz yöntemi ile H4, H5, H6, H7, H8 ve H9 hipotezleri test edilmiştir. Regresyon analizi değişkenler arasında bir ilişkinin olduğu tespit edildikten sonra neden-sonuç ilişkisinin ortaya konması amacıyla yapılmaktadır. Regresyon analizinde amaç değişkenler arasındaki fonksiyonel ilişkiyi açıklamak ve bu ilişkiyi bir modelle tanımlayabilmektir. Bir evrenden elde edilen gözlemler sonucu elde edilen $\mathrm{X}$ ve $\mathrm{Y}$ değişkenleri arasındaki doğrusal ilişki aşağıdaki basit doğrusal regresyon modeli ile verilebilir;

$$
Y=\beta_{0}+\beta_{1} X+\varepsilon
$$


Burada, X: Bağımsız (Açıklayıc1) Değişken, Y: Bağımlı (Açıklanan; Etkilenen; Cevap) Değişken, $\beta_{0}: X=0$ olduğunda bağımlı değişkenin alacağı değer (kesim noktası), $\beta_{1}$ : Regresyon Katsayısı, $\varepsilon$ : Hata terimi (Ortalaması $=0$ ve Varyansı $=\sigma^{2}$, dir.

Çalışmada basit doğrusal regresyon analizi ile test edilmesi amaçlanan hipotezlerden ilk ikisi aşağıdaki gibi belirlenmiştir:

H4: Muhasebe meslek mensupları açısından iç kontrol odaklılığl, iş tatmini üzerinde pozitif etkiye sahiptir.

H5: Muhasebe meslek mensupları açısından dış kontrol odaklılı̆̆l, iş tatmini üzerinde negatif etkiye sahiptir.

Bağımsız değişken "Kontrol Odağı Puanı”, bağımlı değişken "İş Tatmini Puanı" olarak alınmıştır. Oluşturulan model ve regresyon denklemi aşağıdaki gibidir:

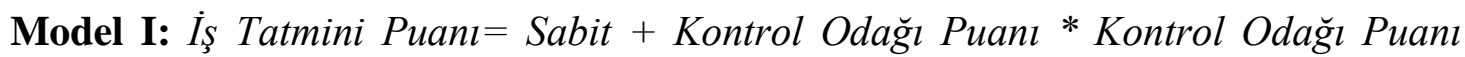
Katsayıs

Model basit doğrusal regresyon analizi ile test edilmiştir. Tablo 17' ye göre model istatistiksel açıdan anlamlıdır $(p=0,000<0,05)$. Bu sonuçlara göre kontrol odağı puanı düştükçe iş tatmini puanı artmaktadır. Dolayısıyla meslek mensubu iç kontrol odaklı bireye doğru yaklaştıkça yaptığı işten duyduğu tatmin artmaktadır. H4 ve H5 hipotezleri doğrulanmıştır. Tablo 17'ye göre regresyon denkleminin son hali şu şekildedir:

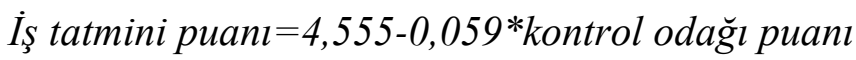

Modele göre kontrol odağ 1 puanındaki 1 birimlik azalış iş tatmini puanını -0,059 birim artırmaktadır. $\mathrm{R}^{2}$ değerine bakıldığında kontrol odağı puanındaki değişmenin, iş tatmini puanındaki değişmenin (varyansın) \%7’ sini açıklayabildiği görülmektedir.

Tablo 17. Regresyon Analizi Sonuçları Model 1

\begin{tabular}{cccccc}
\hline $\begin{array}{c}\text { Model I Bağımsız } \\
\text { Değişken }\end{array}$ & $\begin{array}{c}\text { Standardize } \\
\text { Edilmemiş } \\
\text { Beta }\end{array}$ & $\begin{array}{c}\text { Standart } \\
\text { Hata }\end{array}$ & $\begin{array}{c}\text { Standardize } \\
\text { Edilmiş Beta }\end{array}$ & T Değeri & $\begin{array}{c}\text { Anlam } \\
\text { Düzeyi }\end{array}$ \\
\hline Sabit & 4,555 & 0,162 & & 28,062 &, 000 \\
Kontrol Odă̆ı &,- 059 &, 016 &,- 265 & $-3,645$ &, 000 \\
\hline Bağımlı Değişken: İş Tatmini; R: 0,$265 ; \mathrm{R}^{2}: 0,070 ; \mathrm{F}: 13,288$ & & & \\
\hline
\end{tabular}

H6: Muhasebe meslek mensupları açısından iç kontrol odaklılığ üzerinde pozitif etkiye sahiptir.

H7: Muhasebe meslek mensupları açısından diş kontrol odaklılı̆̆l, iş performansı üzerinde negatif etkiye sahiptir. 
Bağımsız değişken "Kontrol Odağı Puanı”, bağımlı değişken "İş Performansı Puanı" olarak alınmıştır. Oluşturulan model ve regresyon denklemi aşağıdaki gibidir:

Model II: $\dot{I}_{s ̧}$ Performansı Puanı $=$ Sabit + Kontrol Odă̆ Puanı Katsayısı

Model basit doğrusal regresyon analizi ile test edilmiştir. Tablo 18' e göre model istatistiksel açıdan anlamlı değildir $(p=0,435>0,05)$. H6 ve H7 hipotezleri doğrulanamamıştır.

Tablo 18. Regresyon Analizi Sonuçları Model 2

\begin{tabular}{cccccc}
\hline $\begin{array}{c}\text { Model II } \\
\text { Bağımsız } \\
\text { Değişken }\end{array}$ & $\begin{array}{c}\text { Standardize } \\
\text { Edilmemiş Beta }\end{array}$ & $\begin{array}{c}\text { Standart } \\
\text { Hata }\end{array}$ & $\begin{array}{c}\text { Standardize } \\
\text { Edilmiş Beta }\end{array}$ & t Değeri & $\begin{array}{c}\text { Anlam } \\
\text { Düzeyi }\end{array}$ \\
\hline Sabit & 5,895 &, 168 & & 35,061 &, 000 \\
Kontrol Odağı &,- 013 &, 017 &,- 059 &,- 859 &, 435 \\
\hline Bağımlı Değişken: İs Performansi; R: 0,59; R $\mathrm{R}^{2}: 0,03 ; \mathrm{F}: 0,613$ & & & \\
\hline
\end{tabular}

H8: Muhasebe meslek mensupları açısından iç kontrol odaklılı̆̆l, işs stresi üzerinde negatif (stresi azaltan) etkiye sahiptir.

H9: Muhasebe meslek mensupları açısından dış kontrol odaklılığl, işs stresi üzerinde pozitif (stresi arttıran) etkiye sahiptir.

Bağımsız değişken "Kontrol Odağı Puanı”, bağımlı değişken "İ̧s Stresi Puanı” olarak alınmıştır. Oluşturulan model ve regresyon denklemi aşağıdaki gibidir: Katsayıs

Model III: İşs Stresi Puanı = Sabit + Kontrol Odă̆ Puanı * Kontrol Odă̆ Puanı

Model basit doğrusal regresyon analizi ile test edilmiştir. Tablo 19' a göre model istatistiksel açıdan anlamlıdır $(p=0,026<0,05)$. Bu sonuçlara göre kişinin kontrol odağı puanı yüksekse iş stresi puanı da yükselmektedir. Dolayısıyla kişi dış kontrol odaklı bireye doğru yaklaştıkça yaşadığı iş stresi düzeyi artmaktadır. Bu nedenle H8 ve H9 doğrulanmıştır. Tablo 19' a göre regresyon denkleminin son hali şu şekildedir:

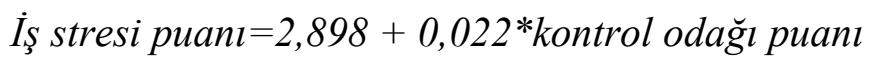

Modele göre kontrol odağı puanındaki 1 birimlik artış iş stresi puanını 0,022 birim artırmaktadır. $R^{2}$ değerine bakıldığında kontrol odağı puanındaki değişmenin, iş stresi puanındaki değişmenin (varyansın) \%2,8' ini açıklayabildiği görülmektedir.

Sonuçlar anlamlıdır $(p=0,026<0,05)$. Bu sonuçlara göre kişinin kontrol odağı puanı yüksekse iş stresi puanı da yükselmektedir. Dolayısıyla kişi dış kontrol odaklı bireye doğru yaklaştıkça yaşadığı iş stresi düzeyi artmaktadır. 
Tablo 19. Regresyon Analizi Sonuçları Model 3

\begin{tabular}{cccccc}
\hline $\begin{array}{c}\text { Model III Bağımsız } \\
\text { Değişken }\end{array}$ & $\begin{array}{c}\text { Standardize } \\
\text { Edilmemiş } \\
\text { Beta }\end{array}$ & Standart Hata & $\begin{array}{c}\text { Standardize } \\
\text { Edilmiş Beta }\end{array}$ & T Değeri & $\begin{array}{c}\text { Anlam } \\
\text { Düzeyi }\end{array}$ \\
\hline Sabit & 2,898 &, 099 & & 29,343 &, 000 \\
Kontrol Odağı &, 022 &, 010 &, 167 & 2,247 &, 026 \\
\hline
\end{tabular}

Bağımlı Değişken: İş Stresi; R: 0,167; R²: 0,028; F: 5,048

\subsubsection{Araştırma Hipotezlerinin Doğrulanma/ Doğrulanmama Durumları}

Yapılan bağımsız gruplar $\mathrm{t}$ testi, korelasyon ve regresyon analizi sonuçlarına göre geçerliliği araştırılan 9 adet hipotezin test sonuçları Tablo 20'de gösterilmiştir.

Tablo 20. Analiz Sonuçlarına Göre Hipotezlerin Doğrulanıp/ Doğrulanmama Durumları

\begin{tabular}{lc}
\hline \multicolumn{1}{c}{ HIPOTEZLER } & SONUÇ \\
\hline H1: Dış kontrol odaklı muhasebe meslek mensupları iç kontrol odaklı muhasebe meslek & Doğrulandı \\
mensuplarına göre daha fazla iş stresi yaşarlar & \\
\hline H2: Dış kontrol odaklı muhasebe meslek mensupları iç kontrol odaklı muhasebe meslek & Doğrulandı \\
mensuplarına göre işlerinden daha az tatmin olurlar & \\
\hline $\begin{array}{l}\text { H3: Dış kontrol odaklı muhasebe meslek mensuplarının iç kontrol odaklı muhasebe } \\
\text { meslek mensuplarına göre iş performansları daha düşüktür }\end{array}$ & Doğrulanmadı \\
\hline $\begin{array}{l}\text { H4: Muhasebe meslek mensupları açısından iç kontrol odaklılığı, iş tatmini üzerinde } \\
\text { pozitif etkiye sahiptir. }\end{array}$ & Doğrulandı \\
\hline $\begin{array}{l}\text { H5: Muhasebe meslek mensupları açısından dış kontrol odaklılığı, iş tatmini üzerinde } \\
\text { negatif etkiye sahiptir. }\end{array}$ & Doğrulandı \\
\hline $\begin{array}{l}\text { H6: Muhasebe meslek mensupları açısından iç kontrol odaklılığı, iş performansı üzerinde } \\
\text { pozitif etkiye sahiptir. }\end{array}$ & Doğrulanmadı \\
\hline $\begin{array}{l}\text { H7: Muhasebe meslek mensupları açısından dış kontrol odaklılığı, iş performansı } \\
\text { üzerinde negatif etkiye sahiptir. }\end{array}$ & Doğrulanmadı \\
\hline $\begin{array}{l}\text { H8: Muhasebe meslek mensupları açısından iç kontrol odaklılığı, iş stresi üzerinde negatif } \\
\text { etkiye sahiptir. }\end{array}$ & Doğrulandı \\
\hline $\begin{array}{l}\text { H9:Muhasebe meslek mensupları açısından dış kontrol odaklılığı, iş stresi üzerinde pozitif } \\
\text { etkiye sahiptir. }\end{array}$ & Doğrulandı \\
\hline
\end{tabular}

Buraya kadar yapılan analiz sonuçlarını özetleyecek olursak; bağımsız gruplar t testi sonuçlarına göre, dış kontrol odağı yapısına sahip meslek mensuplarının, iç kontrol odağı yapısına sahip meslek mensuplarına göre daha fazla iş stresi ve daha az iş tatmini yaşadıkları ortaya konulmuştur. $\mathrm{Bu}$ sonuçlar $\mathrm{H} 1$ ve $\mathrm{H} 2$ hipotezlerinin doğrulandığını göstermekte ve Mitchell, Smyser ve Weed, (1975); Tanç, (2016); Çayl1, (2013) ve Chen ve Silverstone (2008) gibi araştırmacılar tarafından yapılan çalışmaların sonuçlarıyla paralellik göstermektedir. Fakat H3 hipotezini doğrulamak amacıyla yapılan bağımsız gruplar t testi sonuçlarına göre istatistiksel olarak anlamlı bir sonuç ortaya çıkmamıştır. $\mathrm{Bu}$ sonuç literatürdeki çalışmaların birçoğundan farklıdır. Bağımsız gruplar t testi sonrasında yapılan korelasyon analizi sonuçlarının bağımsız gruplar t testi sonuçlarını desteklediği saptanmıştır. 
Regresyon analizleri sonucunda ise H4, H5, H8 ve H9 hipotezleri doğrulanmış, H6 ve H7 hipotezleri ise doğrulanamamıştır. Yapılan basit doğrusal regresyon analizi sonuçlarına göre, iç kontrol odaklılığının muhasebe meslek mensupları açısından iş tatmini üzerinde pozitif, iş stresi üzerinde ise negatif etkisi olduğu görülmüştür. Ancak iş performansı ile iç kontrol odaklılığ 1 arasında istatistiksel olarak bir ilişki saptanamamıştır. Ayrıca dış kontrol odaklılığının muhasebe meslek mensupları açısından iş tatmini üzerinde negatif, iş stresi üzerinde ise pozitif bir etkisi olduğu belirlenmiştir. Fakat iş performansı açısından ise diş kontrol odağı ile ilgili bir ilişki saptanamamıştır.

Bu bulgular, Reed, Kratchman ve Strawser (1994), Young ve Cooper (1995), Hyatt ve Prawitt (2001), Kirkcaldy, Shephard ve Furnham (2002), Chen ve Silverstone (2008), Çaylı (2013) tarafından yapılan çalışmaların sonuçlarıyla paralellik göstermektedir. Bununla birlikte, Filding ve Gali (1982), Frucot ve Shearon (1991) ve Patten (2005) gibi iş performansı ile kontrol odağı arasındaki ilişkiyi inceleyen bazı araştırmaların sonuçlarından farklidir.

\section{SONUÇ VE DEĞERLENDİRME}

Muhasebe meslek mensupları, kendilerinden beklenenleri ve sorumluluklarını yerine getirmeye çalışırken çok çeşitli sorunlarla karşılaşmaktadırlar. Meslek mensuplarının staj öncesinden başlayarak, staja başladıkları dönemlerde, staj bitirme evrelerinde, mesleğe adım atmaya çalıştıkları ilk dönemlerde ve mesleğe başladıktan sonraki dönemlerde olmak üzere her aşamada farklı sıkıntıları söz konusudur. Bu durum, gerek çalıştıkları kurum ya da bağımsız olarak çalışıyorlarsa yönettikleri bürolarda, gerek mükellef bazında, gerek kanun ve mevzuata dayalı problemler vs. olmak üzere, meslek mensuplarının üzerinde çok büyük bir yük ve stres kaynağı oluşturmaktadır. Bu problemler ve stres kaynakları nedeniyle, iş tatminlerinde ve performanslarında düşüş yaşayabilmektedirler.

Meslek mensuplarının yaptıkları işin düşünsel faaliyete dayanması ve mesleğin genel yapısından kaynaklı maddi ve manevi çeşitli riskler içermesi, meslek mensuplarının iş stresi düzeylerini artırmaktadır. Bu durumda ifade edilen iş stresi, iş tatmini ve iş performansı arasındaki ilişkiyi ters yönlü olarak ele aldığımızda; her şeyden önce bireyler hangi mesleği yaparlarsa yapsınlar hayatlarında mutlu olabilmeleri için iş hayatlarında hem maddi hem de manevi olarak yeterli tatmini sağlamaları gerekmektedir. Bireylerin iş hayatlarında tatmini sağlamalarının en önemli aşamalarından biri, işlerini en iyi şekilde yaptıklarına önce kendilerini, sonrasında ise kendisinden beklentisi olan tarafları ikna etmesinden geçmektedir. $\mathrm{Bu}$ durumun oluşmasının yolu ise bireyin yüksek bir iş performansına sahip olmasıdır.

Tüm çalışan bireylerin ve meslek mensuplarının, yukarıda ifade edilen davranışsal ölçütlerinin oluşmasında kendilerinin kişilik yapısı da çok önemli bir yere sahiptir. Kişilik yapısı bireyden bireye farklılık gösterebilmektedir. Bunun nedeni bireylerin yetiştirilme tarzlarının, yetiştikleri çevrenin, aldıkları eğitimin, hayat tecrübelerinin ve sahip oldukları aile yapılarının farklı olmasıdır.

Kontrol odağı davranışı farklı kişilik özelliklerine sahip bireylerin ortak davranış özelliklerinden biridir. Kontrol odağı kavramı kısaca, bireylerin yaşadıkları olayların sonuçlarını nereye bağladıklarıyla ilgilidir. Bununla birlikte kontrol odağı davranışı kişiler arasında iki farklı şekilde kendini göstermektedir. Bunlar iç ve dış kontrol odaklılıktır. 
Yaşadıkları olayların sorumluluğunu kendi davranışlarının sonuçlarına bağlayan bireylere iç kontrol odaklı, kendi dışındaki başka güçlere (diğer insanlar, şans veya kader) bağlayan bireylere de dış kontrol odaklı bireyler denilmektedir.

Kişiliğin belirli bir boyutunu ortaya koyan kontrol odağı kavramı, ortaya atılışının üzerinden geçen yıllara rağmen farklı toplum kesimleri üzerinden yapılan araştırmalara konu olmaya devam etmektedir. Bu doğrultuda yapılan bu çalışmada SM, SMMM ve YMM unvanına sahip meslek mensuplarının kontrol odağı ile iş stresi, iş tatmini ve iş performansı arasındaki ilişki ortaya konulmak istenmiştir. Bu amaçla Türkiye'de faaliyet gösteren 178 muhasebe meslek mensubunun gönüllülük esasına dayalı olarak katıldığı bir anket uygulaması gerçekleştirilmiş ve toplanan veriler analiz edilmiştir.

Araştırma kapsamında elde edilen bulgulara göre, katılımcıların önemli bir kısmının iç kontrol odaklı bir kişilik yapısına sahip oldukları belirlenmiştir. Analiz sonuçlarına göre katılımcıların kontrol odağı puanları ile iş stresi düzeyleri arasında anlamlı ve pozitif yönlü bir ilişki, iş tatmini puanları ile ise anlamlı ve ters yönlü bir ilişki olduğu saptanmıştır. Dolayısıyla muhasebecilik mesleğini icra eden katılımcılar eğer dış kontrol odaklı bir davranış kalıbına yaklaşık tavır sergiliyorlar ise yaşadıkları iş stresi seviyeleri artmaktadır. Buna karşın meslek mensuplarının kontrol odağı puanları arttıkça (meslek mensupları dış kontrol odaklı bireye doğru yaklaştıkça) meslek mensuplarının iş tatmini azalmaktadır. Bununla birlikte katılımcıların kontrol odağı puanları ile iş performansı düzeyleri arasında istatistiksel olarak anlamlı bir ilişki bulunamamıştır.

Çalışma sonucunda ayrıca iç kontrol odağı yapısına sahip muhasebe meslek mensuplarının, dış kontrol odağı yapısına sahip muhasebe meslek mensuplarına göre daha yüksek iş tatmini düzeylerine sahip olduğu tespit edilmiştir. İç kontrol odağı yapısına sahip muhasebe meslek mensuplarının, dış kontrol odağı yapısına sahip meslek mensuplarına göre daha düşük düzeyde iş stresi yaşadıkları belirlenmiştir. Muhasebe meslek mensuplarının hem iç hem de dış kontrol odaklılık yönünden iş performansı düzeyleri arasında herhangi bir ilişki saptanamamiştır.

Kariyer planlamasında muhasebecilik mesleğine yer veren bireyler bu araştırmanın bulgularını ve kontrol odağı ölçeğini dikkate alarak kendilerinin mesleğe uygunluklarını değerlendirebilirler. Muhasebeci istihdam etmeyi planlayan kurumlar ise yine bu araştırmanın yönteminden ve bulgularından hareketle daha doğru personel seçimi yapabilirler. Sonraki çalışmalarda Türkiye'de bölgeler bazında karşılaştırmalı analizler yapılabilir. Böylelikle meslek mensuplarının faaliyet gösterdiği bölgelerin, meslek mensuplarının kişilik yapılarını etkileyip etkilemediği, iç ve dış kontrol odağı davranışının, stresin, iş tatmininin ve performansının bölgeden bölgeye farklılaşıp farklılaşmadığı ortaya konulabilir.

\section{KAYNAKLAR}

Akbolat, Mahmut - Işık Oğuz - Uğurluoğlu Özgür (2011). "Sağlık Çalışanlarının Kontrol Odağı, İş Doyumu, Rol Belirsizliği ve Rol Çatışmasının Karşıllaştırılması", H.Ü. İktisadi ve İdari Bilimler Fakültesi Dergisi, Cilt 29, Sayı 2, ss. 25.

Akkaya, Rıza. (2015). Öğretmenlerin Kontrol Odağı ile İş Doyumu Arasındaki İlişki. Adnan Menderes Üniversitesi Sosyal Bilimler Enstitüsü, Yüksek Lisans Tezi, Aydın. 
Atılmış, Taner. (2016). İşletmelerde Kontrol Odağı Ve Lider Üye Etkileşiminin İş Tatmini Üzerinde Etkisi, Balıkesir Üniversitesi Sosyal Bilimler Enstitüsü, Yüksek Lisans Tezi, Balıkesir.

Basım, H. Nejat - Şeşen Harun. (2008), "Çalışanların Kontrol Odaklarının Örgüt İçi Girişimcilik Tutumları ile İlişkisi: Kamu Sektöründe Bir Araştırma”, Ankara Üniversitesi SBF Dergisi, Cilt 63, Sayı 3, ss. 49-64.

Bingöl, Dursun (2013), İnsan Kaynakları Yönetimi, Cilt 8, Beta Yayınevi, İstanbul.

Candangil Özcan S. - Ceyhan, A. A., (2006), "Denetim odakları farklı lise öğrencilerinin bazı kişisel özelliklerine göre karar vermede özsaygı ve stres düzeyleri”, Sosyal Bilimler Dergisi, Sayı: 2, ss.71-88.

Çakar, Murat. (1997), Lise Son Sınıf Öğrencilerinin Mesleki Olgunluk ile Denetim Odağ1 Düzeylerinin Karşılaştırılması, Marmara Üniversitesi Eğitim Bilimleri Anabilim Dalı, Yüksek Lisans Tezi, İstanbul.

Çaylı, Beril (2013, Kontrol Odağı-İş Tatmini İlişkisi ve Örgütsel Adalet Algısının Aracı Etkisi,. Balıkesir Üniversitesi Sosyal Bilimler Enstitüsü, Yüksek Lisans Tezi, Balıkesir.

Çetin, Fatih (2008), Kişilerarası İlişkilerde Kendilik Algısı, Kontrol Odağı ve Kişilik Yapısının Çatışma Çözme Yaklaşımları Üzerine Etkileri, KHO Savunma Bilimleri Enstitüsü. Yüksek Lisans Tezi, Ankara.

Çınar, Orhan - Karcıoğlu, Fatih (2012), "Büro Yönetimi Bölümü Öğrencilerinin Umutsuzluk Düzeyleri ve Kontrol Odağı İnançları Üzerine Bir Araştırma”, Atatürk Üniversitesi Sosyal Bilimler Enstitüsü Dergisi, Cilt16, Sayı 3, ss. 283-296.

Çinko, S. Burcu (2009), Okul Öncesi Öğretmenlerinin Denetim Odağı Türleri ve Denetim Odaklarının Öğretmenlik Tutumlarına Etkisinin İncelenmesi, Marmara Üniversitesi Eğitim Bilimleri Enstitüsü, Yüksek Lisans Tezi, İstanbul.

Dağ, İhsan. (1991), "Rotter'ın İç-Dış Kontrol Odağı Ölçeğinin (RİDKOÖ ) Üniversite Öğrencileri İçin Güvenirliği ve Geçerliği”. Psikoloji Dergisi, Cilt 7, Sayı 26, ss. 10-17.

Demirkol, İlknur (2006), Avukatlarda İş Doyumu, Tükenmişlik ve Denetim Odağının Bazı Demografik Değişkenler Bağlamında İncelenmesi, Mersin Üniversitesi Sosyal Bilimler Enstitüsü Psikoloji Anabilim Dalı, Yüksek Lisans Tezi, Mersin.

Dilmaç, Oğuz. (2008), “Görsel Sanatlar Öğretmen Adaylarının Denetim Odaklarına İlişkin Algılarının Çeşitli Değişkenlere Göre İncelenmesi”, Güzel Sanatlar Enstitüsü Dergisi, Say1 20, ss. 1-14.

Dönmez, Ali. (1986), “Denetim Odağı: Temel Araştırma Alanları”. Ankara Üniversitesi Eğitim Bilimleri Fakültesi Dergisi. Cilt19, Sayı 1, ss. 259-280. 
Efeoğlu Efe - Özgen Hüseyin. (2007), “ İş-Aile Yaşam Çatışmasının İş Stresi, İş Doyumu ve Örgütsel Bağlılık Üzerindeki Etkileri: İlaç Sektöründe Bir Araştırma”, Çukurova Üniversitesi Sosyal Bilimler Enstitüsü Dergisi:1, Cilt 6, Sayı 2, ss. 237-254.

Fielding, M. ve Gali, M. (1982), Personality and Situational Correlates of Teacher Stress and Burnout, p. 1. American Educational Research Association, (ERIC Document Reproduction Service No. ED219353).

Frucot, Veronique - Shearon, Winston T. (1991), "Budgetary Participation, Locus of Control, and Mexican Managerial Performance and Job Satisfaction", Accounting Review, Cilt 66, Say1 1.

Gangai, M.K.N.- Mahakau, G.C - Sharma, M.V. (2016), Assocition Between Locus of Control and Job Satisfaction in Employees: A Critical Review, The Intarnational Journal of India Psychology, Cilt 3, Sayı 2, ss. 56-58

Gangai, M. K. N-, Mahakud, G. C.- Sharma, M. V. (2016), Association between locus of control and job satisfaction in employees: A critical review. The International Journal of Indian Psychology, 3(2), pp.56-68.

Gangai, M. K. N.- Mahakud, G. C.- Sharma, M. V. (2016), Association between locus of control and job satisfaction in employees: A critical review. The International Journal of Indian Psychology, 3(2), pp.56-68.

George, Darren - Mallery, Paul (2010), SPSS for Windows Step by Step: A Simple Guide and Reference, 17.0 update (10a ed.) Boston: Pearson.

Göçeri, Feyza (2014), Sorumlu Hemşirelerin İş Stresinin İş Doyumu Üzerine Etkisi, Haliç Üniversitesi Sağlık Bilimleri Enstitüsü. Yüksek Lisans Tezi, İstanbul.

Halsey, William D. (1988), Macmillan Contemporary Dictionary, First Edition, ABC Tanıtım Basımevi, İstanbul.

Hexel, Martina (2003), "Alexithymia and Attachment Style in Relation to Locus of Control”, Personality and Individual Differences.

Hyatt, Troy A - Prawitt, Douglas F (2001), "Does Congruence between Audit Structure and Auditors' Locus of Control Affect Job Performance?", The Accounting Review, Cilt 76, Say1 2, pp. 263-274.

Galvin, Benjamin, M.-, Randel, A. E.- Collins, B. J.- Johnson, R. E. (2018), Changing the focus of locus (of control): A targeted review of the locus of control literature and agenda for future research. Journal of Organizational Behavior, 39(7), pp. 820-833.

İbiş, C. (2002), "Bilgi Çağında Muhasebecilik Mesleğinin Geleceği ve Yeni Muhasebeci Kimliği". XVII. Türkiye Muhasebe Kongresi, 10 ve12 Ekim 2002, İstanbul. 
Kıral, Erkan (2012), İlköğretim Okulu Yöneticilerinin Mükemmeliyetçilik Algısı ve Kontrol Odağı ile İlişkisi, Ankara Üniversitesi Eğitim Bilimleri Enstitüsü, Doktora Tezi, Ankara.

Kirkcaldy, Bruce D- Shephard, Roy J - Furnham, Adrian F (2002), "The Influence of Type A Behaviour and Locus of Control Upon Job Satisfaction and Occupational Health", Personality and Individual Differences, Cilt 33, Say1 8, pp. 1361-1371.

Köse, Ahmet. H. (2013), Hal Yönetiminde Çalışanların Tükenmişlik Düzeyi ve İş Tatminlerinin Hizmet Üretimine Etkisi ve Mekansal Yansımaları: İstanbul Büyükşsehir Belediyesi Örneği. Bahçeşehir Üniversitesi Fen Bilimleri Enstitüsü. Yüksek Lisans Tezi, İstanbul.

Krejcie, Robert. V. - Morgan, Daryle. W. (1970), Determining Sample Size For Research Activities. Educational and psychological measurement, 30(3), 607-610.

Küçükkaragöz, Hadiye (1998), İlkokul Öğretmenlerinde Kontrol Odağ1 ve Öğrencilerinin Kontrol Odağının Oluşumuna Etkileri. Dokuz Eylül Üniversitesi Sosyal Bilimler Enstitüsü. Doktora Tezi. İzmir.

Mitchell, Terence R - Smyser, Charles M ve Weed, Stan E (1975), "Locus of Control: Supervision and Work Satisfaction" Academy of Management Journal, Cilt 18, Sayı 3, pp. 623-631.

Özdamar, Kazım (2003), Modern Bilimsel Araştırma Yöntemleri, 1.Bask1, Kaan Kitabevi, Eskişehir.

Özmutaf Nezih. M. (2007), “Örgütlerde Bireysel Performans Unsurları ve Çatışma”, C.Ü. İktisadi ve İdari Bilimler Dergisi, Cilt 8, Sayı 2, ss. 41-42.

Patten, Dennis M. (2005), "An Analysis of The Impact of Locus-of-Control on Internal Auditor Job Performance and Satisfaction", Managerial Auditing Journal, Cilt 20, Say1 9, ss. 1016-1029.

Phares, E. Jerry. (1976), "Locus of Control in Personality. New Jersey". General Learning Pres.

Reed, Sarah A.- Kratchman, Stanley H - Strawser, Robert H. (1994), "Job Satisfaction, Organizational Commitment, and Turnover Intentions of United States Accountants", Accounting, Auditing \& Accountability Journal, Cilt 7, Sayı 1,ss.31-58.

Rotter, Julian. B. (1966), “Generalised Expectancies For Internal Versus External Control of Feinforcement”. Psychological Monographs, Cilt80, ss. 1-28.

Savcı, Gülten (2012), Motive Edici Faktörlerin Çalışanların İş Performansı Ve İşten Ayrılma Niyeti Üzerine Etkisi, Kafkas Üniversitesi Sosyal Bilimler Enstitüsü Sosyal Bilimler Enstitüsü. Yüksek Lisans Tezi, Kars. 
Sergici, Mira (2013), Sigara İçen Üniversite Öğrencilerinde Kontrol Odağı ile SosyotropiOtonomi Kişilik Özelliklerinin İncelenmesi, Haliç Üniversitesi Sosyal Bilimler Enstitüsü. Yüksek Lisans Bölümü, Yayınlanmış Yüksek Lisans Tezi, İstanbul.

Chen, Jui Chen - Silverthorne, Colin (2008), "The Impact of Locus of Control on Job Stress, Job Performance and Job Satisfaction in Taiwan", Leadership \& Organization Development Journal, Cilt 29, Sayı 7, pp. 572-582.

Smith, Peter. C. - Goddard, Micheal (2002), "Performance Management and Operational Research: A Marriage Made in Heaven?", The Journal of the Operational Research Society, Cilt 53, Say1 3:ss. 250.

Solmuş, Tarık (2004), “ İş Yaşamı, Denetim Odağı ve Beş Faktörlük Kişilik Modeli”, Türk Psikoloji Bülteni, Sayı 10, ss. 196.

Sonnentag, Sabine - Michael, Frese (2002), "Performance Concepts and PerformanceTheory". Psychological Management of Individual Performance: A Handbook in the Psychology of Management in Organizations, Der. Sabine Sonnentag, Wiley, Chichester.

Soysal, Abdullah (2009), "İş Yaşamında Stres", www.ceis.org.tr/dergiDocs/makale237.pdf (Erişim: 10 Ocak 2018)

Tabachnick, Barbara G. - Fidell, Linda S. (2013), Using Multivariate Statistics (sixth ed.) Pearson, Boston.

Tanç, Ahmet (2016), "Muhasebe Meslek Mensuplarının İş Tatmini Üzerinde Kontrol Odağ1 Etkisini Tespit Etmeye Yönelik Bir Araştırma", Muhasebe Finansman Dergisi, Sayı, 69, ss. 83-98.

Tümkaya, Songül (2000), "İlkokul Öğretmenlerindeki Denetim Odağı ve Tükenmişlikle İlişkisi”, Pamukkale Üniversitesi Eğitim Fakültesi Dergisi, Cilt 8, Sayı 1, ss.1-2.

Üçüncü, Hasan (2016), “ İş Tatmini Ve Motivasyon”, aves.ktu.edu.tr (Erişim Tarihi: 2 Nisan 2018)

Viswesvaran, Chockalingam - Deniz S. Ones. (2000), 'Perspectives on Models of Job Performance'. International Journal of Selection and Assessment, pp. 216-226.

Yazıcıŏlu, Y. - Erdoğan, S. (2004), SPSS Uygulamalı Bilimsel Araştırma Yöntemleri. Ankara: Detay Yayıncilık .

Yağışan, Nihan ve Sünbül, A. Murat ve Yücalan, Ö.Bike. (2007), "Müzik Bölümü Öğrencilerinin Benlik İmgeleri ve Denetim Odaklarının İncelenmesi”, Selçuk Üniversitesi Sosyal Bilimler Enstitüsü Dergisi, Sayı 22, ss. 243-262.

Yeşilyaprak, Binnur (2015), Eğitimde Bireysel Farklılıklar, 14.Bask1, Nobel Yayıncılık, Ankara. 
Yılmaz, Arif (2016), Algılanan Örgütsel Destek Ortamında İş Stresi ve İş Yaşam Kalitesinin İş Performansı Üzerine Etkisinin Araştırılması: İstanbul'da Bulunan Beş Yıldızlı Otellerde Çalışan Aşçılar Üzerine Bir Araştırma, İstanbul Üniversitesi Sosyal Bilimler Enstitüsü. Doktora Tezi, İstanbul. 
EK 1. Sırasıyla İş Stres (C), İş Tatmini (D) ve İş Performansı (E) Ölçekleri

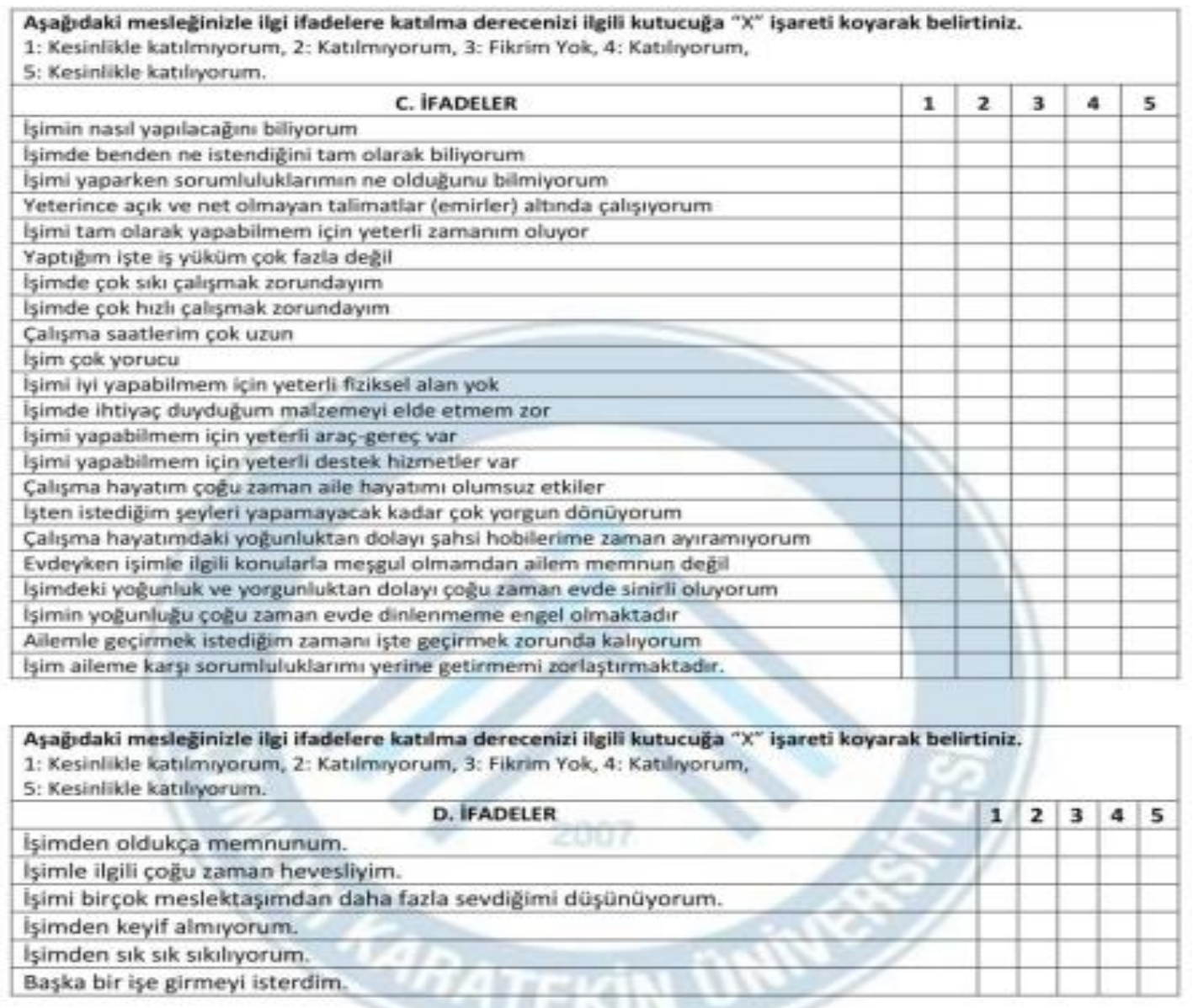

Agağıdaki mesleğinizle ilgili sorulan ilgili kutucuğa " $\mathrm{X}$ " isareti koyarak cevaplayanız.

1: Çok Kötū, 2: Kötü, 3: Biraz Kötü, 4: Orta Seviyede, 5: Biraz lyí, 6: lyi, 7: Cokk lyi

\begin{tabular}{|c|c|c|c|c|c|c|c|}
\hline E. IFADELER & 1 & 2 & 3 & 4 & 5 & 6 & 7 \\
\hline Işinizdeki performansınızı nasıl deḡerlendirirsiniz? & & & & & & & \\
\hline Issinizdeki verimliliğinizi nasıl değerlendirirsiniz? & & & & & & & \\
\hline $\begin{array}{l}\text { Kendinizi meslektaşlannızla kivasladığınızda, meslektaşlannızın } \\
\text { performansını nasıl değerlendïrirsiniz? }\end{array}$ & & & & & & & \\
\hline $\begin{array}{l}\text { Meslektaşlannızla kendinizi kıyasladığınızda kendi performansınızı nasıl } \\
\text { değerlendirirsiniz? }\end{array}$ & & & & & & & \\
\hline
\end{tabular}

